\title{
Data Compilation for AGC-2 Matrix-only Compact Lot A3-P43
}

\author{
J. D. Hunn and M. P. Trammell
}

Revision 0

November 2010

\author{
Prepared for the \\ United States Department of Energy - \\ Office of Nuclear Energy \\ under the \\ Next Generation Nuclear Plant - \\ Advanced Gas Reactor Fuel Development Program
}




\section{DOCUMENT AVAILABILITY}

Reports produced after January 1, 1996, are generally available
free via the U.S. Department of Energy (DOE) Information Bridge.

Web site http://www .osti.gov/bridge

Reports produced before January 1, 1996, may be purchased by members of the public from the following source.

National Technical Information Service 5285 Port Royal Road

Springfield, VA 22161

Telephone 703-605-6000 (1-800-553-6847)

TDD 703-487-4639

Fax 703-605-6900

E-mailinfo@ntis.fedworld.gov

Web site http://www.ntis.gov/support/ordernowabout.htm

Reports are available to DOE employees, DOE contractors, Energy Technology Data Exchange (ETDE) representatives, and

International Nuclear Information System (INIS)

representatives from the following source.

Office of Scientific and Technical Information

P.O. Box 62

Oak Ridge, TN 37831

Telephone 865-576-8401

Fax 865-576-5728

E-mail reports@adonis.osti.gov

Web site http://www .osti.gov/contact.html

This report was prepared as an account of work sponsored by an agency of the United States Government. Neither the United States Government nor any agency thereof, nor any of their employees, makes any warranty, express or implied, or assumes any legal liability or responsibility for the accuracy, completeness, or usefulness of any information, apparatus, product, or process disclosed, or represents that its use would not infringe privately owned rights. Reference herein to any specific commercial product, process, or service by trade name, trademark, manufacturer, or otherwise, does not necessarily constitute or imply its endorsement, recommendation, or favoring by the United States Government or any agency thereof. The views and opinions of authors expressed herein do not necessarily state or reflect those of the United States Government or any agency thereof. 


\title{
Data Compilation for AGC-2 Matrix-only Compact Lot A3-P43
}

\author{
J. D. Hunn and M. P. Trammell \\ Oak Ridge National Laboratory
}

This document is a compilation of fabrication and characterization data for the compact lot A3-P43, which was produced for possible insertion into the second ATR Graphite Creep irradiation test capsule (AGC-2). The compacts were produced by Oak Ridge National Laboratory (ORNL) for the Advanced Gas Reactor Fuel Development and Qualification (AGR) program. This compact lot was fabricated using a graphite/resin blend formulated by INL as a candidate matrix precursor for scale-up of overcoating and compacting processes. The matrix precursor powder for compact lot A3-P43 was a jet milled blend of $64 \mathrm{wt} \%$ natural graphite (Asbury 3482), $16 \mathrm{wt} \%$ synthetic graphite (Graftech GTI-D), and $20 \mathrm{wt} \%$ of a standard novolac resin (Plenco 14043).

The "Matrix Compacts for AGC-2 Irradiation" Specification (INL SPC-1285, Rev. 1) provides the requirements necessary for acceptance of the compacts. Sections 2.03 and 2.04 of SPC-1285 provide the property requirements for the heat-treated compacts. There are requirements on the length, diameter, and matrix density. Section 2.02.01.01 further requests impurity analysis on representative samples from the final compact lot, but there are no specified acceptance criteria. The impurity information will be evaluated by INL as part of a final decision on whether to insert the compacts into the AGC-2 experiment. The procedures for characterizing and qualifying the compacts are outlined in ORNL product inspection plan AGR-CHAR-PIP-16. The measurement of compact length, diameter, and matrix density was performed according to data acquisition method AGR-CHAR-DAM-39. The data report forms generated by this procedure document the product acceptance for the property requirements listed in sections 2.03 and 2.04 of SPC-1285. All compacts selected for irradiation conformed to the specified requirements for length, diameter, and density.

In addition to the characterization data, this report also contains other records relevant to the product acceptance. A history of the material flow and sample naming is included and the compacting process is summarized. In addition to results of the impurity analysis on representative samples from the final compact lot, impurity analysis results are also provided for samples of the graphite, resin, and the graphite/resin blend. A Certificate of Conformance to SPC-1285, Rev. 1 is attached in Appendix B. 
ORNL/TM-2010/306 


\section{Table of Contents}

List of Tables

1 Material identification record for A3-P43

2 Inspection of Length, Diameter, and Matrix Density

3 Inspection of Compact Surface Appearance 11

4 Compacting process conditions 14

5 Impurity analysis of matrix, resin, and graphite 18

6 Inspection of heat-treated compact impurities 25

Appendix A: Compact Machining Drawings 31 Appendix B: Certificate of Conformance 34 


\section{List of Tables}

Table 1-1: Material identification record for A3-P43 compacts

Table 1-2: Disposition of A3-P43 compacts

Table 1-3. Record of assignment of Z-number to fabricated compacts (DRF-39B) 8

Table 2-1. Summary of properties of compact shipped for irradiation 9

Table 2-2. Record of compact acceptance test for dimensions and density (DRF-39A) 10

Table 4-1. Compacting schedule summary 15

Table 4-2. Analysis of cylinders before and after carbonization 17

Table 4-3: Analysis of machined compacts before and after heat-treatment 17

Table 5-1. Summary of feedstock impurities 19

Table 5-2. Impurity analysis report for Asbury 3482 natural graphite lot\# 7602 21

Table 5-3. Impurity analysis report for Graftech GTI_D synthetic graphite \#7782-42-5 22

Table 5-4. Impurity analysis report for Plenco 14043 batch\# 930951 23

Table 5-5. Impurity analysis report for INL graphite/resin Blend D 24

Table 6-1. Summary of heat-treated compact impurities 26

Table 6-2. Impurity analysis report for heat-treated compact A3-P43-Z07 28

Table 6-3. Impurity analysis report for heat-treated compact A3-P43-Z08 29

Table 6-4. Impurity analysis report for heat-treated compact A3-P43-Z15 30 


\section{Material identification record for A3-P43}

Table 1-1 lists the materials used to make the A3-P43 compacts. The graphite/resin blend was shipped from Babcock and Wilcox (B\&W) to ORNL on October 4, 2010. Three completed compacts were shipped to INL on October 28, 2010. Three compacts were also shipped to Shiva Technologies for impurity analysis on October 29, 2010. Fourteen compacts were retained at ORNL. Table 1-2 lists the disposition of each compact. Table 1-3 is a copy of data report form DRF-39B, which lists the specific assignment of final compact ID for each fabricated compact.

Table 1-1: Material identification record for A3-P43 compacts

\begin{tabular}{|l|l|l|}
\hline Sample ID & Parent material & Notes \\
\hline \hline Blend D & $\begin{array}{l}\text { Asbury 3482 natural graphite lot\# 7602 } \\
\text { Graftech GTI-D synthetic graphite CAS\# 7782-42-5 } \\
\text { Plenco 14043 Batch\# 930951 }\end{array}$ & $\begin{array}{l}\text { Parent material information provided by } \\
\text { INL }\end{array}$ \\
\hline A3-P43-\# & Blend D & $\begin{array}{l}\text { Ten cylinders, A3-P43-1 through } \\
\text { A3-P43-10, pressed from Blend D and } \\
\text { carbonized }\end{array}$ \\
\hline $\begin{array}{l}\text { A3-P43-\#-A } \\
\text { and }\end{array}$ & A3-P43-\# & $\begin{array}{l}\text { Two compacts machined from each of ten } \\
\text { carbonized cylinders, A3-P43-1 through } \\
\text { A3-P43-10 }\end{array}$ \\
\hline A3-P43-Z\#\# & $\begin{array}{l}\text { A3-P43-\#-A } \\
\text { and } \\
\text { A3-P43-\#-B }\end{array}$ & $\begin{array}{l}\text { Twenty heat-treated compacts } \\
\text { randomized and relabeled, A3-P43-Z01 } \\
\text { through A3-P43-Z20 (see DRF-39B for } \\
\text { specific assignment record) }\end{array}$ \\
\hline
\end{tabular}

Table 1-2: Disposition of A3-P43 compacts

\begin{tabular}{|l||l||l|l|l|}
\hline \multicolumn{1}{|c||}{ Sent to INL } & \multicolumn{1}{|c||}{ Sent to Shiva } & \multicolumn{3}{c|}{ Retained at ORNL } \\
\hline \hline A3-P43-Z03 & A3-P43-Z07 & A3-P43-Z01 & A3-P43-Z10 & A3-P43-Z17 \\
\hline A3-P43-Z12 & A3-P43-Z08 & A3-P43-Z02 & A3-P43-Z11 & A3-P43-Z18 \\
\hline A3-P43-Z06 (spare) & A3-P43-Z15 & A3-P43-Z04 & A3-P43-Z13 & A3-P43-Z19 \\
\hline & & A3-P43-Z05 & A3-P43-Z14 & A3-P43-Z20 \\
\hline & & A3-P43-Z09 & A3-P43-Z16 & \\
\hline
\end{tabular}


Table 1-3. Record of assignment of Z-number to fabricated compacts (DRF-39B)

\author{
Data Report Form DRF-39B: Compact Tracking
}

\begin{tabular}{|r|l|}
\hline Procedure: & AGR-CHAR-DAM-39 Rev. 0 \\
\hline Operator: & John Hunn \\
\hline Compact lot ID: & A3-P43 \\
\hline Compact Lot description: & Matrix-only compacts from Plenco 14043 \\
\hline Filename: & IImc-agr\AGR\CompactDimensions\A3-P43_DRF39R0.xls \\
\hline
\end{tabular}

\begin{tabular}{|c|c|}
\hline $\begin{array}{c}\text { Compact } \\
\text { Z Number }\end{array}$ & $\begin{array}{c}\text { Compact Fab } \\
\text { Number }\end{array}$ \\
\hline Z01 & $10-A$ \\
\hline$Z 02$ & $8-A$ \\
\hline$Z 03$ & $4-B$ \\
\hline$Z 04$ & $7-B$ \\
\hline$Z 05$ & $4-A$ \\
\hline
\end{tabular}

\begin{tabular}{|c|c|}
\hline $\begin{array}{c}\text { Compact } \\
\text { Z Number }\end{array}$ & $\begin{array}{c}\text { Compact Fab } \\
\text { Number }\end{array}$ \\
\hline$Z 06$ & $5-B$ \\
\hline$Z 07$ & $3-B$ \\
\hline$Z 08$ & $6-A$ \\
\hline$Z 09$ & $2-B$ \\
\hline$Z 10$ & $9-A$ \\
\hline
\end{tabular}

\begin{tabular}{|c|c|}
\hline $\begin{array}{c}\text { Compact } \\
\text { Z Number }\end{array}$ & $\begin{array}{c}\text { Compact Fab } \\
\text { Number }\end{array}$ \\
\hline \hline Z11 & $1-B$ \\
\hline$Z 12$ & $3-A$ \\
\hline$Z 13$ & $6-B$ \\
\hline$Z 14$ & $9-B$ \\
\hline Z15 & $5-A$ \\
\hline
\end{tabular}

\begin{tabular}{|c|c|}
\hline $\begin{array}{c}\text { Compact } \\
\text { Z Number }\end{array}$ & $\begin{array}{c}\text { Compact Fab } \\
\text { Number }\end{array}$ \\
\hline$Z 16$ & $2-A$ \\
\hline$Z 17$ & $1-A$ \\
\hline$Z 18$ & $10-B$ \\
\hline$Z 19$ & $8-B$ \\
\hline$Z 20$ & $7-A$ \\
\hline
\end{tabular}

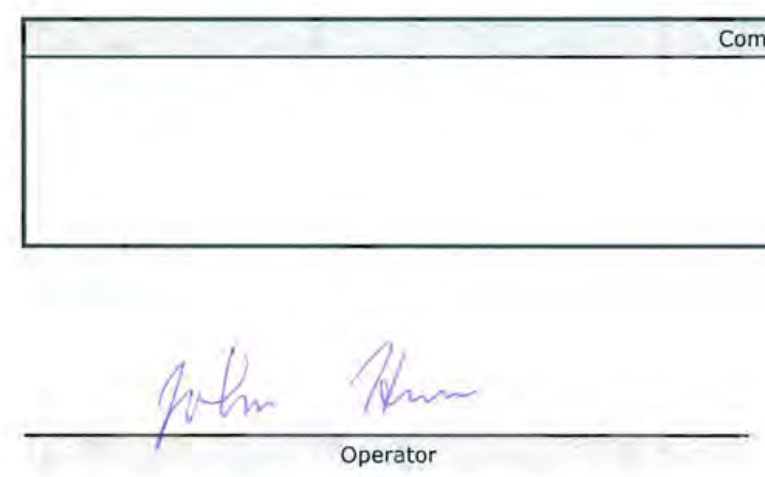

Comments

Operator

$\frac{10.27-10}{\text { Date }}$




\section{Inspection of Length, Diameter, and Matrix Density}

At the end of this section is the data report form DRF-39A associated with the compact lot A3-P43. This data report form summarizes the acceptance testing performed according to the product inspection plan AGR-CHAR-PIP-16. The information in this form covers all the property specifications listed in sections 2.03 and 2.04 of SPC-1285. All compacts met the specified criteria for diameter and matrix density. Seven compacts did not meet the specified criteria for length. These compacts were not used. All compacts selected for irradiation or impurity analysis met all dimensional and density specifications. Note that the specification only requires compacts used for irradiation meet these requirements, so the final determination of this inspection is that the product (compacts used for irradiation) conforms to the specified requirements for length, diameter, and density.

Table 2-1 summarizes the critical properties of the compacts selected for possible insertion in the AGC-2 irradiation experiment. Table 2-2 is a copy of data report form DRF-39A.

Table 2-1. Summary of properties of compact shipped for irradiation

\begin{tabular}{|c|c|c|c|}
\hline Compact ID & Length (mm) & Diameter (mm) & Density $\left(\mathrm{g} / \mathrm{cm}^{3}\right)$ \\
\hline A3-P43-Z03 & 6.315 & 12.74 & 1.759 \\
\hline A3-P43-Z12 & 6.337 & 12.73 & 1.796 \\
\hline A3-P43-Z06 (spare) & 6.350 & 12.74 & 1.753 \\
\hline Specification & $6.299 \leq x \leq 6.350$ & $12.700 \leq x \leq 12.751$ & $1.75 \pm 0.13$ \\
\hline
\end{tabular}


Table 2-2. Record of compact acceptance test for dimensions and density (DRF-39A)

Data Report Form DRF-39A: Compact Diameter, Lenath, and Density

\begin{tabular}{|c|}
\hline Procedure: AGR-CHAR-DAM-39 Rev-0 \\
\hline Operator: John Hunn \\
\hline Compact lot ID: A3-P43 \\
\hline Compact Lot description: Matrix-only compacts from Plenco 14043 \\
\hline Filename: IImc-agr/AGRICompactDimensionsIA3-P43_DRF39R0.xis \\
\hline
\end{tabular}

\begin{tabular}{|c|}
\hline Vertical height gauge callibration due date: $3 / 22 / 11$ \\
\hline Digital caliper calibration due date: $5 / 11 / 11$ \\
\hline Gauge blocks calibration due date: $11 / 7 / 12$ \\
\hline Analytical balance calibration due date: $9 / 13 / 11$ \\
\hline
\end{tabular}

\begin{tabular}{|c|}
\hline Acceptance criteria for compact length: $\geq 6.299$ and $\leq 6.350 \mathrm{~mm}$ \\
\hline Acceptance criteria for compact diameter: $\geq 12.700$ and $\leq 12.751 \mathrm{~mm}$ \\
\hline Acceptance criteria for compact mass: For information only \\
\hline Acceptance criteria for compact density: $1.75 \pm 0.13 \mathrm{~g} / \mathrm{cm}^{3}$ \\
\hline
\end{tabular}

\begin{tabular}{|c|c|c|c|c|c|c|c|c|}
\hline \multirow{2}{*}{$\begin{array}{l}\text { Compact } \\
\text { ID Number }\end{array}$} & \multirow{2}{*}{$\begin{array}{l}\text { Mass } \\
(9)\end{array}$} & \multirow{2}{*}{$\begin{array}{l}\text { Length } \\
(\mathrm{mm})\end{array}$} & \multicolumn{3}{|c|}{ Diameter (mm) } & \multirow{2}{*}{$\begin{array}{c}\text { Volume } \\
\left(\mathrm{cm}^{3}\right)\end{array}$} & \multirow{2}{*}{$\begin{array}{l}\text { Density } \\
\left(\mathrm{g} / \mathrm{cm}^{3}\right)\end{array}$} & \multirow{2}{*}{$\begin{array}{c}\text { Accept? } \\
\text { (pass or fail) }\end{array}$} \\
\hline & & & $0^{\circ}$ & $90^{\circ}$ & Average & & & \\
\hline 201 & 1.5043 & 6.374 & 12.72 & 12.72 & 12.72 & 0.8100 & 1.8572 & fail \\
\hline 202 & 1.4972 & 6.372 & 12.73 & 12.73 & 12.73 & 0.8110 & 1.8461 & fail \\
\hline 203 & 1.4163 & 6.315 & 12.74 & 12.74 & 12.74 & 0.8050 & 1.7594 & pass \\
\hline 204 & 1.3601 & 6.330 & 12.71 & 12.71 & 12.71 & 0.8031 & 1.6935 & pass \\
\hline 205 & 1.4917 & 6.363 & 12.74 & 12.74 & 12.74 & 0.8111 & 1.8390 & fail \\
\hline 206 & 1.4190 & 6.350 & 12.74 & 12.74 & 12.74 & 0.8095 & 1.7530 & pass \\
\hline 207 & 1.3907 & 6.330 & 12.72 & 12.72 & 12.72 & 0.8044 & 1.7289 & pass \\
\hline 208 & 1.4853 & 6.344 & 12.74 & 12.74 & 12.74 & 0.8087 & 1.8366 & pass \\
\hline 209 & 1.3853 & 6.314 & 12.72 & 12.72 & 12.72 & 0.8024 & 1.7265 & pass \\
\hline $\mathrm{Z10}$ & 1.4195 & 6.334 & 12.72 & 12.72 & 12.72 & 0.8049 & 1.7636 & pass \\
\hline 211 & 1.3843 & 6.336 & 12.72 & 12.72 & 12.72 & 0.8052 & 1.7193 & pass \\
\hline $\mathrm{Z12}$ & 1.4473 & 6.337 & 12.73 & 12.72 & 12.73 & 0.8059 & 1.7958 & pass \\
\hline 213 & 1.4229 & 6.325 & 12.73 & 12.73 & 12.73 & 0.8050 & 1.7675 & pass \\
\hline 214 & 1.4476 & 6.323 & 12.72 & 12.72 & 12.72 & 0.8035 & 1.8016 & pass \\
\hline Z15 & 1.4819 & 6.344 & 12.74 & 12.74 & 12.74 & 0.8087 & 1.8324 & pass \\
\hline 216 & 1.4338 & 6.333 & 12.72 & 12.72 & 12.72 & 0.8048 & 1.7816 & pass \\
\hline 217 & 1.4633 & 6.352 & 12.73 & 12.73 & 12.73 & 0.8085 & 1.8100 & fail \\
\hline 218 & 1.4603 & 6.360 & 12.72 & 12.73 & 12.73 & 0.8088 & 1.8054 & Fall \\
\hline $\mathrm{Z19}$ & 1.3749 & 6.358 & 12.72 & 12.72 & 12.72 & 0.8080 & 1.7017 & fail \\
\hline 220 & 1.4725 & 6.353 & 12.74 & 12,74 & 12.74 & 0.8099 & 1.8182 & fail \\
\hline
\end{tabular}

Seven compacts failed length specification (too long). These will not be umments

All but one compact had side fissures and end damage.

All but one compact had side fissures and end damage.

$\mathrm{Z} 193$ and $\mathrm{Z} 12$ had minor side fissures and end damage and will be shipped for irradiation.

zo6 had minor side fissures and end damage, it will be shipped as a spare.
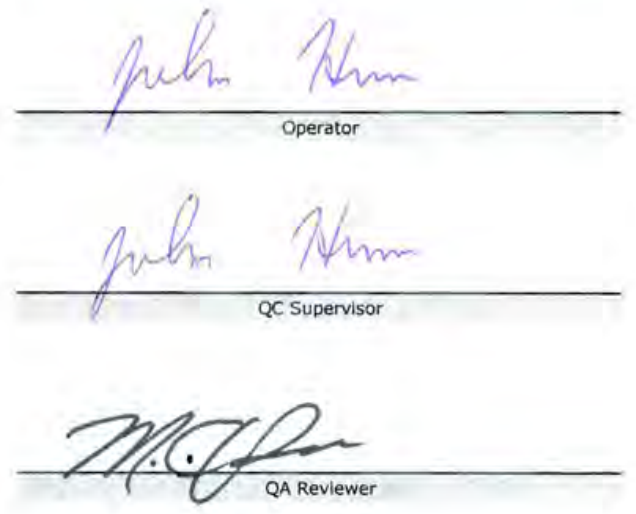

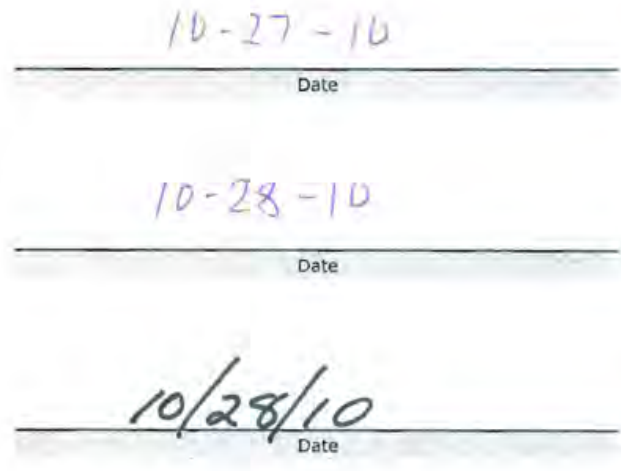




\section{Inspection of Compact Surface Appearance}

All but 1 compact had obvious surface fissures on the sides (Figure 3-1) and surface damage on one or both ends (Figure 3-2). The one compact that did not have obvious side fissures and end damage (A3-P43-Z19) was $0.008 \mathrm{~mm}$ too long and was not selected for irradiation. Two of the compacts that exhibited only minor surface fissures (Figure 3-3) and end damage (Figure 3-4 and Figure 3-5) were selected for irradiation (see Table 1-2). A third compact was selected as a spare, based on the fact that it also only exhibited minor side fissures and end damage.

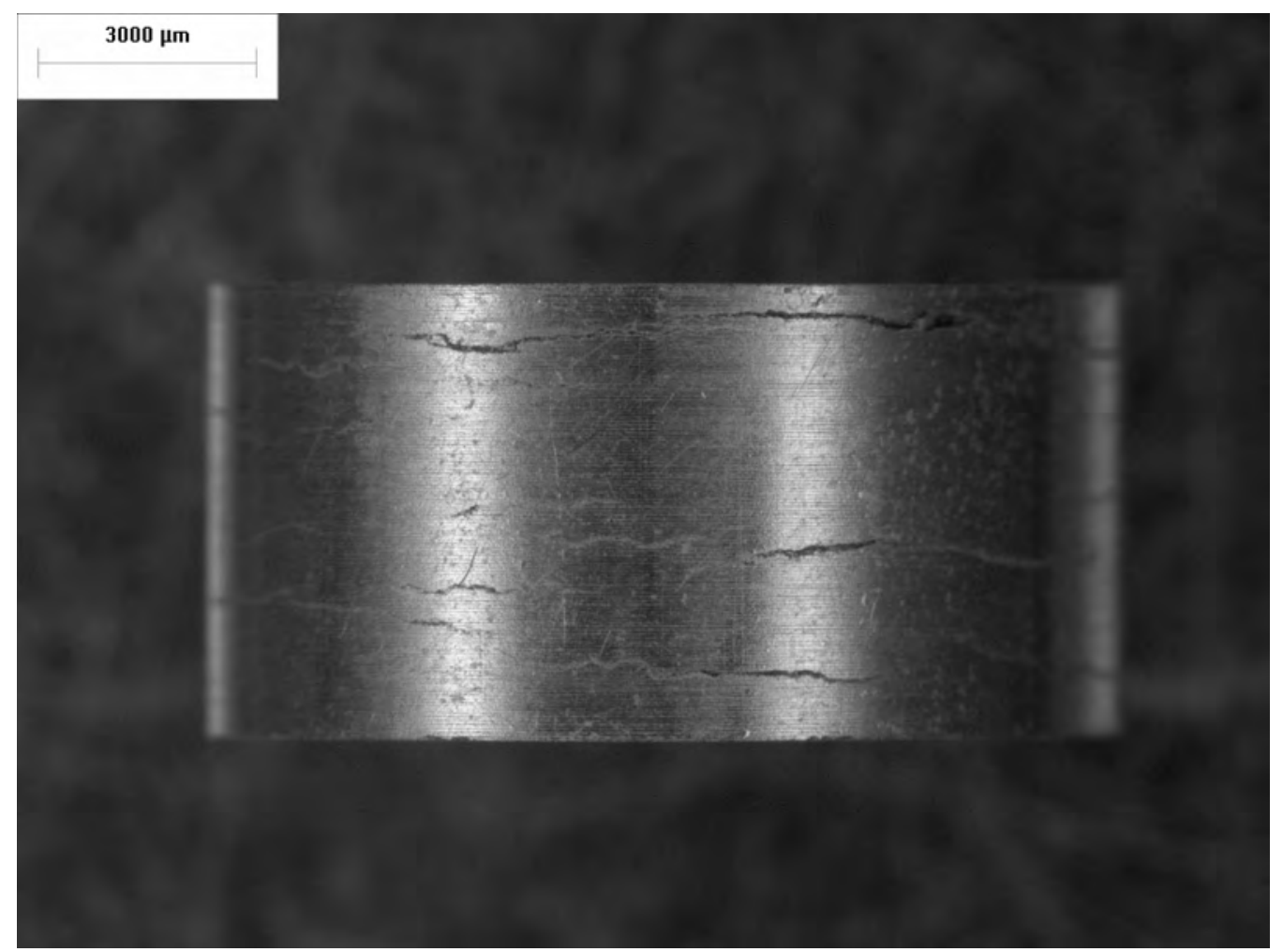

Figure 3-1. Fissures were observed to a varying degree on the sides of most compacts. An example of side fissures on compact A3-H08-Z04 from a similar compact lot is shown. 


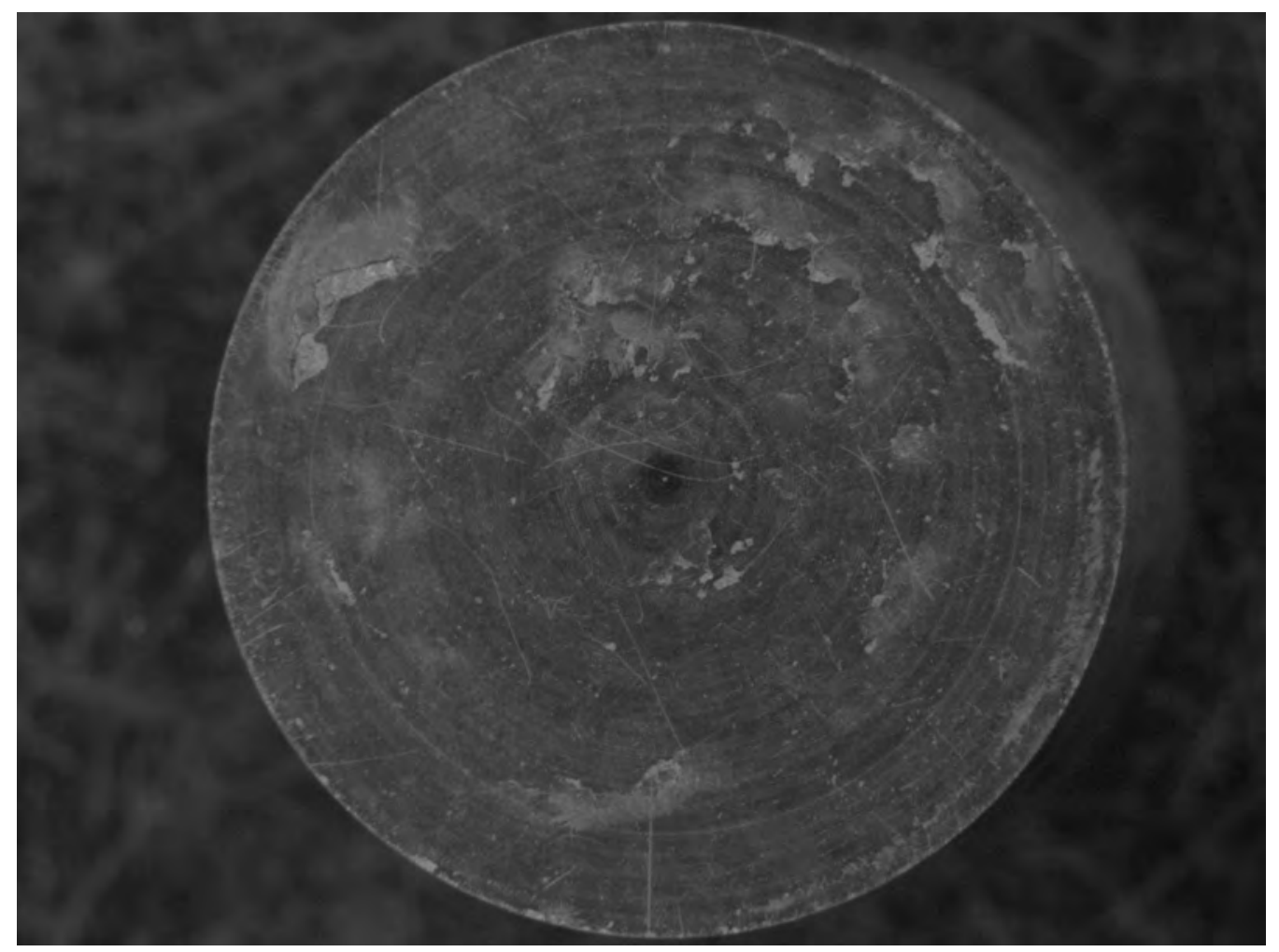

Figure 3-2. End faces of many compacts showed damage that looked like flakes of material were delaminating and sometimes breaking away. Compact A3-H08-Z04 is shown.

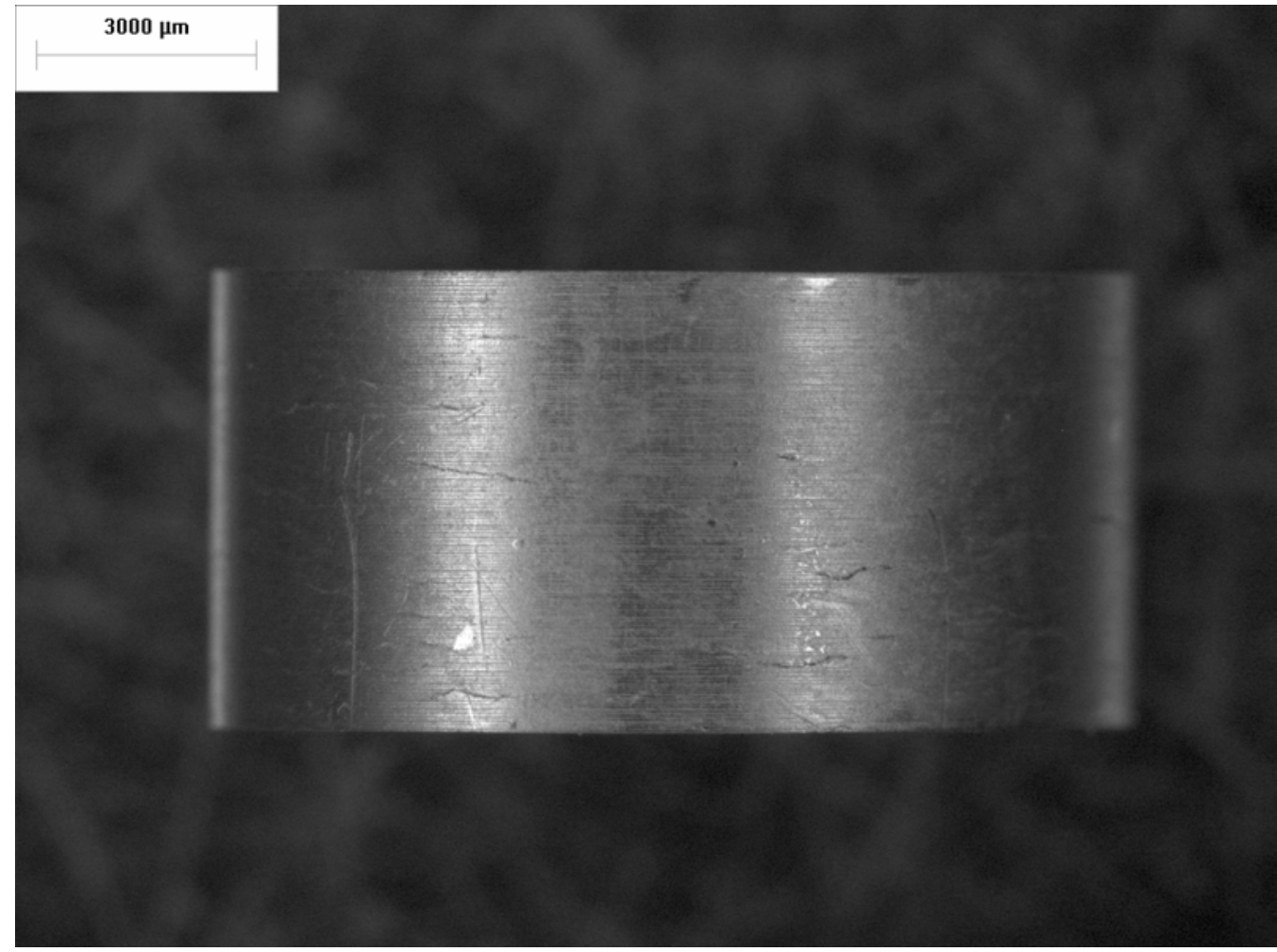

Figure 3-3. Minor side fissure on compact A3-P43-Z03 (selected for irradiation). 


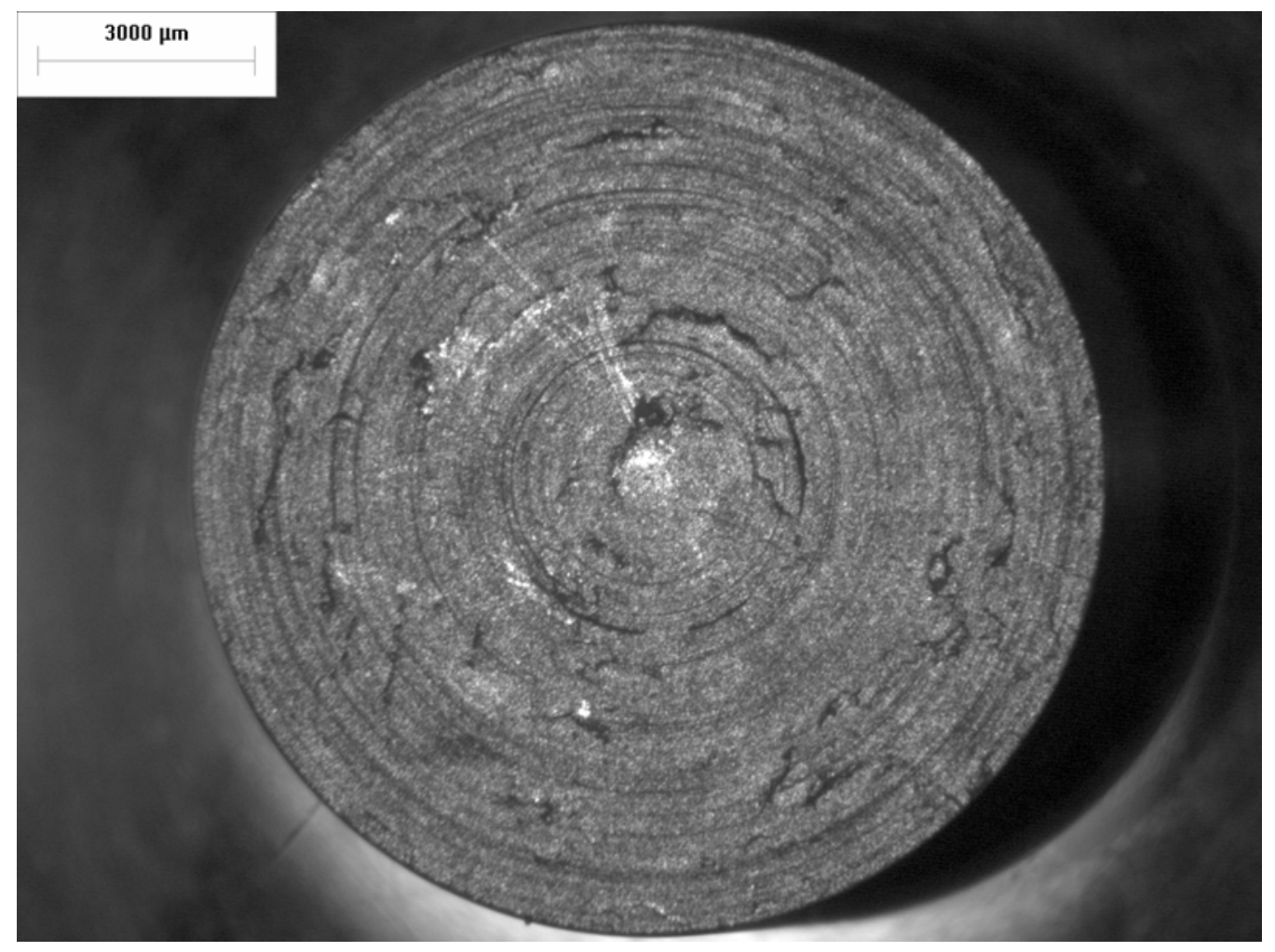

Figure 3-4. Minor damage on one end of compact A3-P43-Z03 (selected for irradiation).

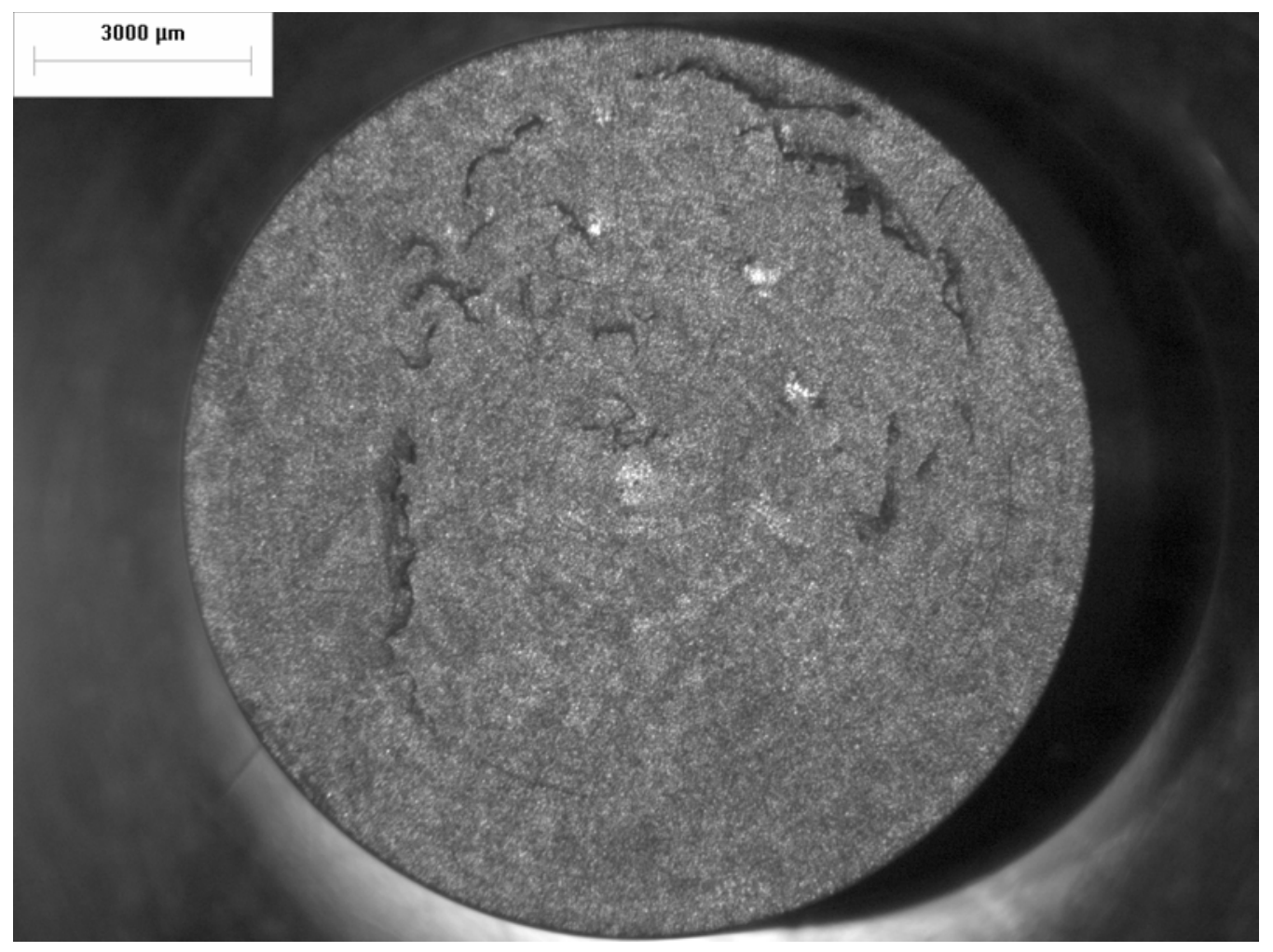

Figure 3-5. Minor damage on other end of compact A3-P43-Z03 (selected for irradiation). 


\section{Compacting process conditions}

Initial matrix-only compacting tests were performed using parameters suggested by INL, which were selected based on manufacturer provided resin properties and previous experiments with overcoated material. These test compacts exhibited problems including delamination or fracture during ejection from the die and development of fissures during carbonization. The higher fraction of resin in the matrix-only compacts compared to compacts made from overcoated particles may have been a contributing factor to the difficulties encountered. To reduce the observed cracking, additional development was carried out before the final matrix-only compacts were fabricated. As part of this development, several compacts were made at various pressing conditions to determine the most effective fabrication methods. A summary of the final fabrication procedure is outlined below. This procedure was able to produce compacted cylinders with minimal visible flaws in the as-compacted (green) state. However, fissures still developed during carbonization.

AGC-2 matrix-only compacts needed to be nominally $12.7 \mathrm{~mm}$ in diameter, $6.35 \mathrm{~mm}$ in length, and $1.75 \mathrm{~g} / \mathrm{cm}^{3}$ in density. Normally, a custom die would be made to produce compacts with the required dimensions. However, a limited time was available for fabrication of these compacts in order to have them available for inclusion in the AGC-2 irradiation test. The required fabrication schedule made it infeasible to obtain a new compacting die with a diameter that would yield the desired final compact diameter after heat-treatment. As an alternative approach, a slightly oversized (15.24 mm diameter) die was used to produce 10 cylinders from each matrix blend that were then machined into the final 20 compacts. The die was single-acting, that is, the top punch moved and the bottom punch was fixed. To obtain two compacts from each carbonized cylinder, a minimum length of at least $25.4 \mathrm{~mm}$ long was desired to allow for gripping of the cylinder and machining loss. However, the compacting die, which had $\sim 75 \mathrm{~mm}$ of available length for loading, was not tall enough to hold the amount of as-received matrix precursor powder required to produce a compacted cylinder at least $25.4 \mathrm{~mm}$ long. The jet milled powder had a low bulk density, so a pre-compacting method for the as-received powder was developed to allow the required amount of feed material to fit in the available die. Another die (25.4 mm diameter) was used to produce $\sim 1 \mathrm{~g} / \mathrm{cm}^{3}$ slugs, which were re-granulated into a coarse powder that would work with the $15.24 \mathrm{~mm}$ diameter compacting die. These low density slugs were made by filling the $25.4 \mathrm{~mm}$ diameter die at room temperature with the as-received matrix precursor blend and pressing to $8 \mathrm{kN}$. The slugs were then broken into granules and passed through a U.S. Standard \#20 (850 $\mu \mathrm{m}$ nominal opening) sieve to remove any large chunks.

Table 4-1 provides a summary of the critical steps in the compacting schedule. All AGC-2 matrix-only compacts were made using standard operating procedure AGR-COMP-SOP-10, "Production of AGC Irradiation Specimens" and the following pressing schedule. Using the precompacting method described above, charges were prepared and weighed out while the compacting die, top punch, and bottom punch were heated simultaneously to $130 \pm 1^{\circ} \mathrm{C}$. The compact charge weight was calculated to produce a compact of the required length and density, based on empirical data on weight loss and shrinkage. During heating, the inner diameter and contact surfaces of the top and bottom punches were lightly sprayed with McLube 860 mold release agent and allowed to dry. The charge was poured into the compacting die within an approximately 30 second long period. The top punch was put in place and the matrix precursor 
material was allowed to warm up in the die for an additional 20-30 seconds before the programmed compacting sequence was initiated on the Promess press. The press ram was advanced at $1 \mathrm{~mm} / \mathrm{sec}$, taking approximately 20 seconds to reach the target position. This target position was chosen to produce a compact of the desired length. At $1 \mathrm{~mm}$ short of the target position, there was a 1 second delay. This delay provided additional relaxation time for the material and reduced the peak force applied during compacting. After the 1 second delay, the press continued to move to the target position. Once at the target position, the press held position for 60 seconds. After the hold, the press retracted and an ejection block was set in place to allow the lower punch and cylinder to be ejected from the bottom of the die.

Table 4-1. Compacting schedule summary

\begin{tabular}{|c|l|l|l|}
\hline Step & \multicolumn{1}{|c|}{ Action } & \multicolumn{1}{c|}{ Timing } & \multicolumn{1}{c|}{ Comments } \\
\hline \hline 1 & Load die & $\sim 30 \mathrm{sec}$ to load & \\
\hline 2 & Delay & $\sim 30 \mathrm{sec}$ & Allow matrix precursor material to heat up \\
\hline 3 & Initiate program & & \\
\hline 4 & Move to position & $\sim 20 \mathrm{sec}$ & Pressing at $1 \mathrm{~mm} / \mathrm{sec}$ \\
\hline 5 & Delay & $1 \mathrm{sec}$ & Hold position $1 \mathrm{~mm}$ short of target position \\
\hline 6 & Move to position & $1 \mathrm{sec}$ & Continue to target position at $1 \mathrm{~mm} / \mathrm{sec}$ \\
\hline 7 & Delay & $60 \mathrm{sec}$ & Hold position \\
\hline 8 & Move to position & N/A & Retract for ejection \\
\hline 9 & Move to position & N/A & Eject part at $3 \mathrm{~mm} / \mathrm{sec}$ \\
\hline
\end{tabular}

The compacted cylinders were carbonized per procedure AGR-COMP-SOP-04, "Carbonizing Compacts" by heating to $950^{\circ} \mathrm{C}$ at a rate of $1^{\circ} \mathrm{C} / \mathrm{min}$ in flowing helium, followed by a 1 hour hold. The carbonized cylinders were machined according to drawing AGR-COMP-DWG-03, "AGC Compact Drawing" (see appendix A). Cylinders were first turned down to the target diameter. Prior to cutting two compacts of the target length from each cylinder, a thin layer of material was removed from the end to square the cylinder. The two machined compacts were identified by adding " $\mathrm{A}$ " or "B" to the fabrication ID relative to their location within the original compact (A being closest to the top of the die). Most of the B compacts came from near the middle of the cylinder. However, two of the compacted cylinders (A3-P43-7 and A3-P43-8) fractured during machining. For these cylinders, the B compact was taken from closer to the bottom of the cylinder. After machining, the compacts were heat-treated per procedure AGRCOMP-SOP-05, "Heat-treating Compacts" by heating to $1800^{\circ} \mathrm{C}$ under vacuum at a rate of $20^{\circ} \mathrm{C} / \mathrm{min}$, followed by a 1 hour hold. The main purpose of the heat-treatment process was to reduce impurity content in the compacts. Compacts were heat-treated after machining to reduce the potential for contamination after the heat-treatment step.

Based on previous experience with AGR matrix materials, most dimensional changes in the pressed cylinders were expected to occur during carbonization. However, compacts can also undergo dimensional changes during heat-treatment. These changes are usually a consistent minor shrinkage and can be compensated for by using empirical data to oversize the compacts. During initial testing, it was determined that the dimensional change induced by the heattreatment of the A3-P43 matrix material was inconsistent. Some test compacts shrank, while others grew in length. For this reason, compacts were machined to a length close to the middle of the specified final length for the heat-treated compacts. This provided the most flexibility and 
allowed for re-machining of compacts that were too long. Upon inspection of the heat-treated compacts, there were enough compacts with an acceptable length, so re-machining was not necessary.

Table 4-2 provides dimensional analysis for the cylinders before and after carbonization. Table 4-3 provides dimensional analysis for the machined compacts before and after heat-treatment. Table 4-2 also lists the compaction force required to press each green compact. Average density was determined from the measured weight and dimensions assuming a cylindrical geometry.

Because of the presence of fissures in the cylinders and compacts, it is difficult to draw conclusions from the analysis of the data in Table 4-2 and Table 4-3. These fissures were visible in most of the final heat-treated compacts and are discussed in section 3 . These fissures can add to the length of the compact and produce an error in the calculated density.

Fractional weight loss after carbonization was consistent in all the cylinders that were measured. Fractional change in length after carbonization was less consistent due to the presence of fissures in the cylinders. Table 4-3 shows that many of the machined compacts were longer after heattreatment. This was also most likely due to the formation or expansion of these fissures. There was also a slight weight loss after heat-treatment. The calculated density of the compacts taken from closer to the top of the cylinder was higher than those taken from lower down because the compacting force was greater closer to the moving punch. 
Table 4-2. Analysis of cylinders before and after carbonization

\begin{tabular}{|c|c|c|c|c|c|c|c|c|c|c|c|c|c|}
\hline \multirow[b]{2}{*}{ Fabrication ID } & \multirow{2}{*}{$\begin{array}{l}\text { Compaction } \\
\text { Force (Mpa) }\end{array}$} & \multicolumn{4}{|l|}{ Green } & \multicolumn{4}{|l|}{ Carbonized } & \multicolumn{4}{|c|}{ Fractional change from green to carbonized } \\
\hline & & Length $(\mathrm{mm})$ & Dia $(\mathrm{mm})$ & Mass (g) & Density $\left(\mathrm{g} / \mathrm{cm}^{2}\right)$ & Length (mm) & Dia (mm) & Mass (g) & Density $\left(\mathrm{g} / \mathrm{cm}^{2}\right)$ & Length & Dia & Mass & Density \\
\hline A3-P43-1 & 25.4 & 25.60 & 15.24 & 8.3975 & 1.798 & 24.95 & 15.06 & 7.7432 & 1.742 & 0.975 & 0.988 & 0.922 & 0.969 \\
\hline A3-P43-2 & 26.5 & 25.98 & 15.23 & 8.4087 & 1.777 & 25.19 & 15.06 & 7.7460 & 1.726 & 0.970 & 0.989 & 0.921 & 0.972 \\
\hline A3-P43-3 & 27.6 & 25.91 & 15.23 & 8.4076 & 1.781 & 25.10 & 15.06 & 7.7463 & 1.733 & 0.969 & 0.989 & 0.921 & 0.973 \\
\hline A3-P43-4 & 30.5 & 25.45 & 15.22 & 8.4082 & 1.816 & 24.81 & 15.06 & 7.7420 & 1.752 & 0.975 & 0.989 & 0.921 & 0.965 \\
\hline A3-P43-5 & 29.0 & 25.56 & 15.22 & 8.4022 & 1.807 & 24.89 & 15.04 & 7.7369 & 1.750 & 0.974 & 0.988 & 0.921 & 0.968 \\
\hline A3-P43-6 & 36.5 & 25.37 & 15.21 & 8.3789 & 1.818 & 24.75 & 15.04 & 7.7107 & 1.754 & 0.976 & 0.989 & 0.920 & 0.965 \\
\hline A3-P43-7 & 23.3 & 25.93 & 15.30 & 8.4135 & 1.765 & 25.14 & 15.02 & 7.7438 & 1.738 & 0.970 & 0.982 & 0.920 & 0.985 \\
\hline A3-P43-8 & 29.1 & 25.55 & 15.27 & 8.4035 & 1.796 & 24.83 & 15.03 & 7.7320 & 1.755 & 0.972 & 0.984 & 0.920 & 0.977 \\
\hline A3-P43-9 & 31.6 & 25.40 & 15.18 & 8.4118 & 1.830 & 24.74 & 15.04 & 7.7512 & 1.764 & 0.974 & 0.991 & 0.921 & 0.964 \\
\hline A3-P43-10 & 30.1 & 25.37 & 15.22 & $\begin{array}{l}8.4110 \\
8.3836\end{array}$ & 1.816 & 24.66 & 14.86 & 7.7242 & 1.806 & 0.972 & 0.976 & 0.921 & 0.994 \\
\hline
\end{tabular}

Table 4-3: Analysis of machined compacts before and after heat-treatment

\begin{tabular}{|c|c|c|c|c|c|c|c|c|c|c|c|c|c|}
\hline \multirow[b]{2}{*}{ Fabrication ID } & \multirow[b]{2}{*}{ Characterization ID } & \multicolumn{4}{|l|}{ Carbonized } & \multicolumn{4}{|l|}{ Heat Treated } & \multicolumn{4}{|c|}{ Fractional change from carbonized to heat treated } \\
\hline & & Length $(\mathrm{mm})$ & Dia (mm) & Mass $(\mathrm{g})$ & Density $\left(\mathrm{g} / \mathrm{cm}^{2}\right)$ & Length $(\mathrm{mm})$ & Dia (mm) & Mass $(\mathrm{g})$ & Density $\left(\mathrm{g} / \mathrm{cm}^{2}\right)$ & Length & Dia & Mass & Density \\
\hline A3-P43-1-A & A3-P43-Z17 & 6.34 & 12.73 & 1.4706 & 1.8225 & 6.352 & 12.73 & 1.4633 & 1.8100 & 1.002 & 1.000 & 0.995 & 0.993 \\
\hline A3-P43-1-B & A3-P43-Z11 & 6.34 & 12.73 & 1.3917 & 1.7247 & 6.336 & 12.72 & 1.3843 & 1.7193 & 0.999 & 0.999 & 0.995 & 0.997 \\
\hline A3-P43-2-A & A3-P43-Z16 & 6.31 & 12.72 & 1.4400 & 1.7958 & 6.333 & 12.72 & 1.4338 & 1.7816 & 1.004 & 1.000 & 0.996 & 0.992 \\
\hline A3-P43-2-B & A3-P43-Z09 & 6.31 & 12.72 & 1.3916 & 1.7355 & 6.314 & 12.72 & 1.3853 & 1.7265 & 1.001 & 1.000 & 0.995 & 0.995 \\
\hline A3-P43-3-A & A3-P43-Z12 & 6.31 & 12.71 & 1.4528 & 1.8147 & 6.337 & 12.73 & 1.4473 & 1.7944 & 1.004 & 1.002 & 0.996 & 0.989 \\
\hline A3-P43-3-B & A3-P43-Z07 & 6.32 & 12.71 & 1.3966 & 1.7417 & 6.330 & 12.72 & 1.3907 & 1.7289 & 1.002 & 1.001 & 0.996 & 0.993 \\
\hline A3-P43-4-A & A3-P43-Z05 & 6.32 & 12.72 & 1.4973 & 1.8644 & 6.363 & 12.74 & 1.4917 & 1.8390 & 1.007 & 1.002 & 0.996 & 0.986 \\
\hline A3-P43-4-B & A3-P43-Z03 & 6.30 & 12.72 & 1.4222 & 1.7765 & 6.315 & 12.74 & 1.4163 & 1.7594 & 1.002 & 1.002 & 0.996 & 0.990 \\
\hline A3-P43-5-A & A3-P43-Z15 & 6.31 & 12.73 & 1.4874 & 1.8520 & 6.344 & 12.74 & 1.4819 & 1.8324 & 1.005 & 1.001 & 0.996 & 0.989 \\
\hline A3-P43-5-B & A3-P43-Z06 & 6.33 & 12.73 & 1.4247 & 1.7684 & 6.350 & 12.74 & 1.4190 & 1.7530 & 1.003 & 1.001 & 0.996 & 0.991 \\
\hline A3-P43-6-A & A3-P43-Z08 & 6.31 & 12.72 & 1.4905 & 1.8588 & 6.344 & 12.74 & 1.4853 & 1.8366 & 1.005 & 1.002 & 0.997 & 0.988 \\
\hline A3-P43-6-B & A3-P43-Z13 & 6.30 & 12.72 & 1.4288 & 1.7847 & 6.325 & 12.73 & 1.4229 & 1.7675 & 1.004 & 1.001 & 0.996 & 0.990 \\
\hline A3-P43-7-A & A3-P43-Z20 & 6.32 & 12.72 & 1.4779 & 1.8402 & 6.353 & 12.74 & 1.4725 & 1.8182 & 1.005 & 1.002 & 0.996 & 0.988 \\
\hline A3-P43-7-B & A3-P43-Z04 & 6.34 & 12.70 & 1.3671 & 1.7022 & 6.330 & 12.71 & 1.3601 & 1.6935 & 0.998 & 1.001 & 0.995 & 0.995 \\
\hline A3-P43-8-A & A3-P43-Z02 & 6.34 & 12.72 & 1.5028 & 1.8653 & 6.372 & 12.73 & 1.4972 & 1.8461 & 1.005 & 1.001 & 0.996 & 0.990 \\
\hline A3-P43-8-B & A3-P43-Z19 & 6.36 & 12.72 & 1.3817 & 1.7096 & 6.358 & 12.72 & 1.3749 & 1.7017 & 1.000 & 1.000 & 0.995 & 0.995 \\
\hline A3-P43-9-A & A3-P43-Z10 & 6.31 & 12.72 & 1.4991 & 1.8696 & 6.334 & 12.72 & 1.4195 & 1.7636 & 1.004 & 1.000 & 0.947 & 0.943 \\
\hline A3-P43-9-B & A3-P43-Z14 & 6.32 & 12.73 & 1.4565 & 1.8107 & 6.323 & 12.72 & 1.4476 & 1.8016 & 1.000 & 0.999 & 0.994 & 0.995 \\
\hline A3-P43-10-A & A3-P43-Z01 & 6.35 & 12.72 & 1.5106 & 1.8720 & 6.374 & 12.72 & 1.5043 & 1.8572 & 1.004 & 1.000 & 0.996 & 0.992 \\
\hline A3-P43-10-B & A3-P43-Z18 & 6.35 & 12.72 & 1.4678 & 1.8190 & 6.360 & 12.72 & 1.4603 & 1.8068 & 1.002 & 1.000 & 0.995 & 0.993 \\
\hline
\end{tabular}




\section{$5 \quad$ Impurity analysis of matrix, resin, and graphite}

Samples of the natural and synthetic graphite, resin, and matrix precursor blend D were sent to Shiva Technologies for impurity analysis. The matrix precursor powder for compact lot A3-P43 was a jet milled blend of $64 \mathrm{wt} \%$ natural graphite (Asbury 3482), 16 wt\% synthetic graphite (Graftech GTI-D), and $20 \mathrm{wt} \%$ of a standard novolac resin (Plenco 14043). The resin and matrix precursor blend were carbonized prior to shipment to Shiva. The carbonization process was used to remove volatiles that would interfere with the impurity analysis. Approximately 5 grams of resin and graphite/resin blend were loaded into separate quartz trays and then placed into a tube furnace. The samples were heated to $950^{\circ} \mathrm{C}$ at a rate of $5^{\circ} \mathrm{C} / \mathrm{min}$ and held at $950^{\circ} \mathrm{C}$ for 1 hour. The furnace power was cut and the samples cooled to room temperature. The samples were then loaded into glass vials and shipped to SHIVA for full scan glow discharge mass spectrometry (GDMS) analysis, along with samples of the natural and synthetic graphite.

Table 5-1 is a compilation of the impurity analysis results. Impurities that could not be detected above the analysis threshold value are reported as less than values $(<)$ and appear in gray. Values marked as less than or equal to $(=<)$ indicate that a measurable value of the element was obtained, but that this element may have come from the Shiva sample preparation. Prior to GDMS analysis, Shiva poured the powder samples into a Teflon mold with a binder material. The binder was mostly indium, but may also have contained other elements, as indicated in the analysis report by the "=<" symbol. The resin showed very high values for F, but these were marked as semiquantitative $(\sim)$ and probably came from the Teflon mold. The natural graphite was very high in $\mathrm{Si}$ and also high in $\mathrm{Mg}, \mathrm{Al}, \mathrm{S}$, and $\mathrm{Fe}$. The synthetic graphite was high in $\mathrm{Cu}$. The impurities in the graphite carried over to the jet milled blend. The resin had high levels of $\mathrm{Al}, \mathrm{Si}, \mathrm{S}$, and $\mathrm{Ca}$ that appeared to also carry over into the jet milled blend.

Copies of the Shiva Technologies certified impurity analysis data sheets for the natural and synthetic graphite are provided in Table 5-2 and Table 5-3. A copy of the certified impurity analysis data sheet for the Plenco resin is provided in Table 5-4. A copy of the certified impurity analysis data sheet for the graphite/resin blend made from these materials (INL Blend D) is provided in Table 5-5.

Samples of the final heat treated compacts were also sent to Shiva for analysis. These results are presented in section. As discussed in that section 6, heat-treatment of the compacts removed some of the impurities present in the graphite/resin blend. 
Table 5-1. Summary of feedstock impurities

\begin{tabular}{|c|c|c|c|c|}
\hline \multirow{2}{*}{ Element } & \multicolumn{4}{|c|}{ Concentration (ppm wt) } \\
\hline & Asbury 3482 & GTI-D & Plenco 14043 & INL Blend D \\
\hline$\overline{\mathrm{Li}}$ & $<<0.01$ & $\begin{array}{c}<0.01 \\
\end{array}$ & 0.61 & $<<0.01$ \\
\hline $\mathrm{Be}$ & $<0.01$ & $<0.01$ & $<0.01$ & $<0.01$ \\
\hline B & 0.24 & 0.77 & 0.1 & 0.56 \\
\hline $\mathrm{C}$ & Matrix & Matrix & Matrix & Matrix \\
\hline $\mathrm{N}$ & - & - & - & - \\
\hline $\mathrm{O}$ & - & - & - & - \\
\hline$F$ & $\sim 20$ & $\sim 10$ & $\sim 360$ & $\sim 10$ \\
\hline $\mathrm{Na}$ & 1.5 & 11 & 29 & 1.9 \\
\hline $\mathrm{Mg}$ & 80 & 1.2 & 23 & 79 \\
\hline $\mathrm{Al}$ & 29 & 0.9 & 130 & 37 \\
\hline $\mathrm{Si}$ & 710 & 2.7 & 330 & 670 \\
\hline $\mathrm{P}$ & 0.82 & $<0.1$ & 2 & 1.4 \\
\hline S & 25 & 10 & 460 & 39 \\
\hline $\mathrm{Cl}$ & 2.5 & 7.8 & 4.6 & 7.4 \\
\hline $\mathrm{K}$ & 0.2 & $<0.1$ & 3.6 & $<0.1$ \\
\hline $\mathrm{Ca}$ & 8.2 & 3.2 & 580 & 51 \\
\hline $\mathrm{Sc}$ & $<0.05$ & $<0.05$ & $<0.05$ & $<0.05$ \\
\hline $\mathrm{Ti}$ & 2.3 & 2.2 & 5 & 2.2 \\
\hline $\mathrm{V}$ & 0.45 & 9.9 & 0.07 & 1.4 \\
\hline $\mathrm{Cr}$ & $<0.5$ & $<0.5$ & $<0.5$ & 1.8 \\
\hline $\mathrm{Mn}$ & 0.55 & $<0.05$ & 0.2 & 0.71 \\
\hline $\mathrm{Fe}$ & 38 & 1.1 & 10 & 40 \\
\hline Co & $<0.05$ & $<0.05$ & $<0.05$ & 0.17 \\
\hline $\mathrm{Ni}$ & 0.25 & 0.25 & 0.4 & 0.95 \\
\hline $\mathrm{Cu}$ & 2.5 & 120 & 5.1 & 64 \\
\hline $\mathrm{Zn}$ & 0.4 & $<0.1$ & $=<1.3$ & $<0.1$ \\
\hline $\mathrm{Ga}$ & $<0.1$ & $<0.1$ & $<0.1$ & $<0.1$ \\
\hline $\mathrm{Ge}$ & $<0.1$ & $<0.1$ & $<0.1$ & $<0.1$ \\
\hline As & $<0.1$ & $<0.1$ & $<0.1$ & $<0.1$ \\
\hline $\mathrm{Se}$ & $<0.1$ & $<0.1$ & $<0.1$ & $<0.1$ \\
\hline $\mathrm{Br}$ & 0.41 & $<0.1$ & 0.25 & 1.7 \\
\hline $\mathrm{Rb}$ & $<0.05$ & $<0.05$ & $<0.05$ & $<0.05$ \\
\hline $\mathrm{Sr}$ & 0.08 & $<0.05$ & 0.33 & 0.06 \\
\hline $\mathrm{Y}$ & 0.2 & $<0.05$ & $<0.05$ & 0.09 \\
\hline $\mathrm{Zr}$ & 0.6 & 0.14 & $<0.05$ & 1.9 \\
\hline $\mathrm{Nb}$ & $<0.1$ & $<0.1$ & $<0.1$ & $<0.1$ \\
\hline Mo & $<0.05$ & 0.09 & 0.05 & 0.29 \\
\hline $\mathrm{Ru}$ & $<0.1$ & $<0.1$ & $<0.1$ & $<0.1$ \\
\hline $\mathrm{Rh}$ & $<0.1$ & $<0.1$ & $<0.1$ & $<0.1$ \\
\hline $\mathrm{Pd}$ & $<0.1$ & $<0.1$ & $<0.1$ & $<0.1$ \\
\hline $\mathrm{Ag}$ & $<0.1$ & $<0.1$ & $<0.1$ & $<0.1$ \\
\hline $\mathrm{Cd}$ & $<0.1$ & $<0.1$ & $<0.1$ & $<0.1$ \\
\hline In & Binder & Binder & Binder & Binder \\
\hline
\end{tabular}


Table 5-1. Summary of feedstock impurities (continued)

\begin{tabular}{|c|c|c|c|c|}
\hline \multirow{2}{*}{ Element } & \multicolumn{4}{|c|}{ Concentration (ppm wt) } \\
\hline & Asbury 3482 & GTI-D & Plenco 14043 & INL Blend D \\
\hline $\mathrm{Sn}$ & $<0.5$ & $<0.5$ & $<0.5$ & $<0.5$ \\
\hline $\mathrm{Sb}$ & $<0.5$ & $<0.5$ & $<0.5$ & $<0.5$ \\
\hline $\mathrm{Te}$ & $<0.1$ & $<0.1$ & $<0.1$ & $<0.1$ \\
\hline $\mathrm{I}$ & $<20$ & $=<80$ & $=<280$ & $<20$ \\
\hline Cs & $<0.1$ & $<0.1$ & $<0.1$ & $<0.1$ \\
\hline $\mathrm{Ba}$ & 0.8 & $<0.1$ & $<0.1$ & $<0.1$ \\
\hline $\mathrm{La}$ & $<0.5$ & $=<2$ & $=<11$ & $<0.5$ \\
\hline $\mathrm{Ce}$ & $<0.5$ & $<0.5$ & $<0.5$ & $<0.5$ \\
\hline $\operatorname{Pr}$ & $<0.05$ & $<0.05$ & $=<1.5$ & $<0.05$ \\
\hline $\mathrm{Nd}$ & $<0.05$ & $<0.05$ & $<0.05$ & $<0.05$ \\
\hline $\mathrm{Sm}$ & $<0.05$ & $<0.05$ & $<0.05$ & $<0.05$ \\
\hline $\mathrm{Eu}$ & $<0.05$ & $<0.05$ & $<0.05$ & $<0.05$ \\
\hline $\mathrm{Gd}$ & $<0.05$ & $<0.05$ & $<0.05$ & $<0.05$ \\
\hline $\mathrm{Tb}$ & $<0.05$ & $<0.05$ & $<0.05$ & $<0.05$ \\
\hline Dy & $<0.05$ & $<0.05$ & $<0.05$ & $<0.05$ \\
\hline Ho & $<0.05$ & $<0.05$ & $<0.05$ & $<0.05$ \\
\hline $\mathrm{Er}$ & $<0.05$ & $<0.05$ & $<0.05$ & $<0.05$ \\
\hline $\mathrm{Tm}$ & $<0.05$ & $<0.05$ & $<0.05$ & $<0.05$ \\
\hline $\mathrm{Yb}$ & $<0.05$ & $<0.05$ & $<0.05$ & $<0.05$ \\
\hline $\mathrm{Lu}$ & $<0.05$ & $<0.05$ & $<0.05$ & $<0.05$ \\
\hline Hf & $<0.05$ & $<0.05$ & $<0.05$ & $<0.05$ \\
\hline $\mathrm{Ta}$ & $<5$ & $<5$ & $<5$ & $<5$ \\
\hline $\mathrm{W}$ & 0.15 & $<0.05$ & 0.07 & 0.21 \\
\hline $\mathrm{Re}$ & $<0.05$ & $<0.05$ & $<0.05$ & $<0.05$ \\
\hline Os & $<0.05$ & $<0.05$ & $<0.05$ & $<0.05$ \\
\hline $\mathrm{Ir}$ & $<0.05$ & $<0.05$ & $<0.05$ & $<0.05$ \\
\hline $\mathrm{Pt}$ & $<0.05$ & $<0.05$ & $<0.05$ & $<0.05$ \\
\hline $\mathrm{Au}$ & $<0.1$ & $<0.1$ & $<0.1$ & $<0.1$ \\
\hline $\mathrm{Hg}$ & $<0.5$ & $<0.5$ & $<0.5$ & $<0.5$ \\
\hline $\mathrm{Tl}$ & $<0.1$ & $<0.1$ & $<0.1$ & $<0.1$ \\
\hline $\mathrm{Pb}$ & $<0.5$ & $<0.5$ & $<0.5$ & $<0.5$ \\
\hline $\mathrm{Bi}$ & $<0.1$ & $<0.1$ & $<0.1$ & $<0.1$ \\
\hline Th & $<0.05$ & $<0.05$ & $<0.05$ & $<0.05$ \\
\hline $\mathrm{U}$ & $<0.05$ & $<0.05$ & $<0.05$ & $<0.05$ \\
\hline
\end{tabular}


Table 5-2. Impurity analysis report for Asbury 3482 natural graphite lot\# 7602

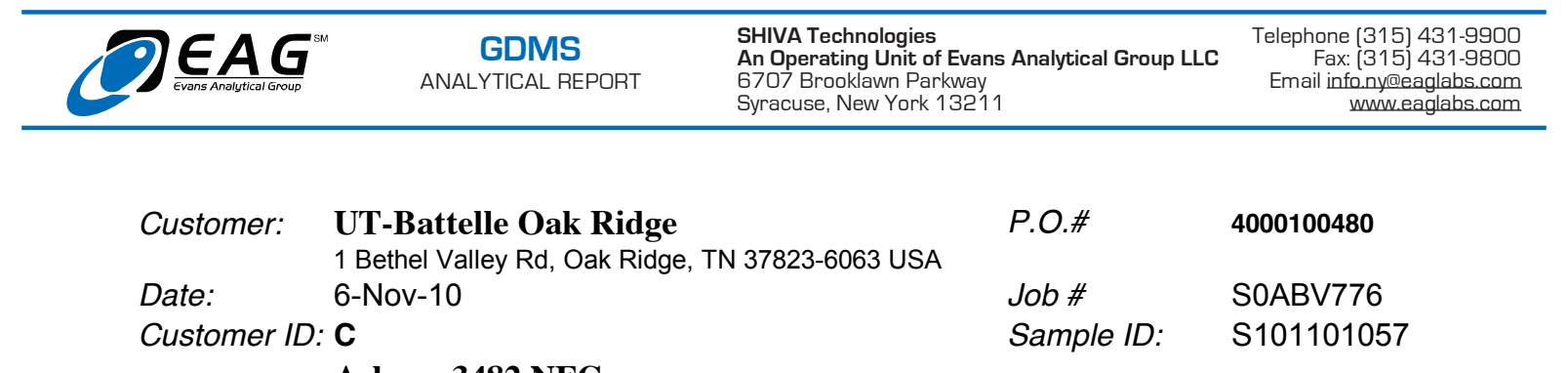

\section{Asbury 3482 NFG}

\begin{tabular}{|c|c|c|c|}
\hline Element & $\begin{array}{c}\text { Concentration } \\
\text { [ppm wt ] }\end{array}$ & Element & $\begin{array}{l}\text { Concentration } \\
\text { [ppm wt ] }\end{array}$ \\
\hline $\mathrm{Li}$ & $<0.01$ & $\mathrm{Pd}$ & $<0.1$ \\
\hline $\mathrm{Be}$ & $<0.01$ & $\mathrm{Ag}$ & $<0.1$ \\
\hline$B$ & 0.24 & $\mathrm{Cd}$ & $<0.1$ \\
\hline $\mathrm{C}$ & Matrix & $\ln$ & Binder \\
\hline $\mathrm{N}$ & - & $\mathrm{Sn}$ & $<0.5$ \\
\hline $\mathrm{O}$ & - & $\mathrm{Sb}$ & $<0.5$ \\
\hline $\mathrm{F}$ & $\sim 20$ & $\mathrm{Te}$ & $<0.1$ \\
\hline $\mathrm{Na}$ & 1.5 & 1 & $<20$ \\
\hline $\mathrm{Mg}$ & 80 & Cs & $<0.1$ \\
\hline $\mathrm{Al}$ & 29 & $\mathrm{Ba}$ & 0.8 \\
\hline $\mathrm{Si}$ & 710 & $\mathrm{La}$ & $<0.5$ \\
\hline $\mathrm{P}$ & 0.82 & $\mathrm{Ce}$ & $<0.5$ \\
\hline $\mathrm{S}$ & 25 & $\mathrm{Pr}$ & $<0.05$ \\
\hline $\mathrm{Cl}$ & 2.5 & $\mathrm{Nd}$ & $<0.05$ \\
\hline $\mathrm{K}$ & 0.2 & $\mathrm{Sm}$ & $<0.05$ \\
\hline $\mathrm{Ca}$ & 8.2 & $\mathrm{Eu}$ & $<0.05$ \\
\hline Sc & $<0.05$ & $\mathrm{Gd}$ & $<0.05$ \\
\hline $\mathrm{Ti}$ & 2.3 & $\mathrm{~Tb}$ & $<0.05$ \\
\hline $\mathrm{V}$ & 0.45 & Dy & $<0.05$ \\
\hline $\mathrm{Cr}$ & $<0.5$ & $\mathrm{Ho}$ & $<0.05$ \\
\hline $\mathrm{Mn}$ & 0.55 & $\mathrm{Er}$ & $<0.05$ \\
\hline $\mathrm{Fe}$ & 38 & Tm & $<0.05$ \\
\hline $\mathrm{Co}$ & $<0.05$ & $\mathrm{Yb}$ & $<0.05$ \\
\hline $\mathrm{Ni}$ & 0.25 & Lu & $<0.05$ \\
\hline $\mathrm{Cu}$ & 2.5 & $\mathrm{Hf}$ & $<0.05$ \\
\hline $\mathrm{Zn}$ & 0.4 & $\mathrm{Ta}$ & $<5$ \\
\hline $\mathrm{Ga}$ & $<0.1$ & $\mathrm{~W}$ & 0.15 \\
\hline $\mathrm{Ge}$ & $<0.1$ & $\mathrm{Re}$ & $<0.05$ \\
\hline As & $<0.1$ & Os & $<0.05$ \\
\hline $\mathrm{Se}$ & $<0.1$ & $\mathrm{Ir}$ & $<0.05$ \\
\hline $\mathrm{Br}$ & 0.41 & $\mathrm{Pt}$ & $<0.05$ \\
\hline $\mathrm{Rb}$ & $<0.05$ & $\mathrm{Au}$ & $<0.1$ \\
\hline $\mathrm{Sr}$ & 0.08 & $\mathrm{Hg}$ & $<0.5$ \\
\hline $\mathrm{Y}$ & 0.2 & $\mathrm{TI}$ & $<0.1$ \\
\hline$\overline{Z r}$ & 0.6 & $\mathrm{~Pb}$ & $<0.5$ \\
\hline $\mathrm{Nb}$ & $<0.1$ & $\mathrm{Bi}$ & $<0.1$ \\
\hline Mo & $<0.05$ & Th & $<0.05$ \\
\hline $\mathrm{Ru}$ & $<0.1$ & $\mathrm{U}$ & $<0.05$ \\
\hline $\mathrm{Rh}$ & $<0.1$ & & \\
\hline
\end{tabular}

Page 1 of 1 - GDMS

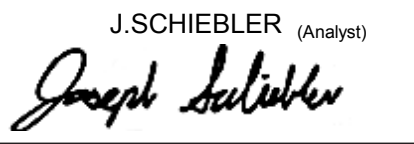

This report shall not be reproduced except in full without written approval of the laboratory. The recording of false, fictitious, or fraudulent statements or entries on the document may be punished as a felony under federal law 
Table 5-3. Impurity analysis report for Graftech GTI_D synthetic graphite \#7782-42-5

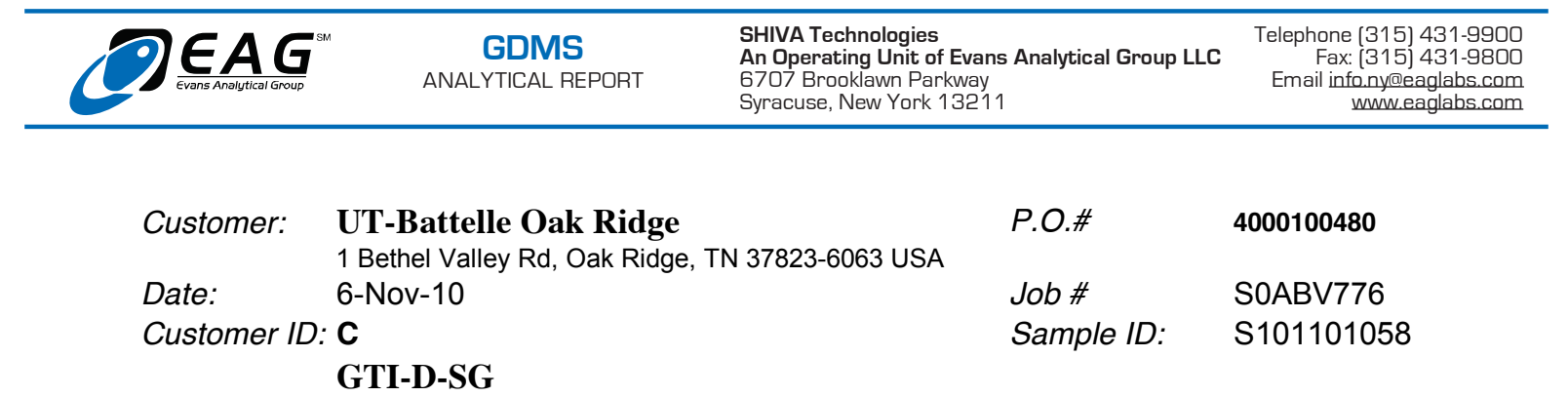

\section{GTI-D-SG}

\begin{tabular}{|c|c|c|c|}
\hline Element & $\begin{array}{l}\text { Concentration } \\
\text { [ ppm wt ] }\end{array}$ & Element & $\begin{array}{l}\text { Concentration } \\
\text { [ppm wt ] }\end{array}$ \\
\hline $\mathrm{Li}$ & $<0.01$ & $\mathrm{Pd}$ & $<0.1$ \\
\hline $\mathrm{Be}$ & $<0.01$ & $\mathrm{Ag}$ & $<0.1$ \\
\hline$B$ & 0.77 & $\mathrm{Cd}$ & $<0.1$ \\
\hline $\mathrm{C}$ & Matrix & $\ln$ & Binder \\
\hline $\mathrm{N}$ & - & $\mathrm{Sn}$ & $<0.5$ \\
\hline $\mathrm{O}$ & - & $\mathrm{Sb}$ & $<0.5$ \\
\hline $\mathrm{F}$ & $\sim 10$ & $\mathrm{Te}$ & $<0.1$ \\
\hline $\mathrm{Na}$ & 11 & 1 & $=<80$ \\
\hline $\mathrm{Mg}$ & 1.2 & Cs & $<0.1$ \\
\hline $\mathrm{Al}$ & 0.9 & $\mathrm{Ba}$ & $<0.1$ \\
\hline $\mathrm{Si}$ & 2.7 & $\mathrm{La}$ & $=<2$ \\
\hline $\mathrm{P}$ & $<0.1$ & $\mathrm{Ce}$ & $<0.5$ \\
\hline $\mathrm{S}$ & 10 & $\mathrm{Pr}$ & $<0.05$ \\
\hline $\mathrm{Cl}$ & 7.8 & $\mathrm{Nd}$ & $<0.05$ \\
\hline $\mathrm{K}$ & $<0.1$ & $\mathrm{Sm}$ & $<0.05$ \\
\hline $\mathrm{Ca}$ & 3.2 & $\mathrm{Eu}$ & $<0.05$ \\
\hline Sc & $<0.05$ & $\mathrm{Gd}$ & $<0.05$ \\
\hline $\mathrm{Ti}$ & 2.2 & $\mathrm{~Tb}$ & $<0.05$ \\
\hline $\mathrm{V}$ & 9.9 & Dy & $<0.05$ \\
\hline $\mathrm{Cr}$ & $<0.5$ & $\mathrm{Ho}$ & $<0.05$ \\
\hline $\mathrm{Mn}$ & $<0.05$ & $\mathrm{Er}$ & $<0.05$ \\
\hline $\mathrm{Fe}$ & 1.1 & $\mathrm{Tm}$ & $<0.05$ \\
\hline $\mathrm{Co}$ & $<0.05$ & $\mathrm{Yb}$ & $<0.05$ \\
\hline $\mathrm{Ni}$ & 0.25 & Lu & $<0.05$ \\
\hline $\mathrm{Cu}$ & 120 & $\mathrm{Hf}$ & $<0.05$ \\
\hline $\mathrm{Zn}$ & $<0.1$ & $\mathrm{Ta}$ & $<5$ \\
\hline $\mathrm{Ga}$ & $<0.1$ & $\mathrm{~W}$ & $<0.05$ \\
\hline $\mathrm{Ge}$ & $<0.1$ & $\mathrm{Re}$ & $<0.05$ \\
\hline As & $<0.1$ & Os & $<0.05$ \\
\hline $\mathrm{Se}$ & $<0.1$ & $\mathrm{Ir}$ & $<0.05$ \\
\hline $\mathrm{Br}$ & $<0.1$ & $\mathrm{Pt}$ & $<0.05$ \\
\hline $\mathrm{Rb}$ & $<0.05$ & $\mathrm{Au}$ & $<0.1$ \\
\hline $\mathrm{Sr}$ & $<0.05$ & $\mathrm{Hg}$ & $<0.5$ \\
\hline $\mathrm{Y}$ & $<0.05$ & $\mathrm{TI}$ & $<0.1$ \\
\hline$\overline{Z r}$ & 0.14 & $\mathrm{~Pb}$ & $<0.5$ \\
\hline $\mathrm{Nb}$ & $<0.1$ & $\mathrm{Bi}$ & $<0.1$ \\
\hline Mo & 0.09 & Th & $<0.05$ \\
\hline $\mathrm{Ru}$ & $<0.1$ & $\mathrm{U}$ & $<0.05$ \\
\hline $\mathrm{Rh}$ & $<0.1$ & & \\
\hline
\end{tabular}

$\sim$ Semiquantitative Values

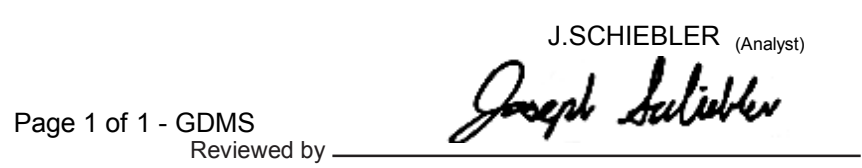

This report shall not be reproduced except in full without written approval of the laboratory. The recording of false, fictitious, or fraudulent statements or entries on the document may be punished as a felony under federal law 
ORNL/TM-2010/306

Table 5-4. Impurity analysis report for Plenco 14043 batch\# 930951

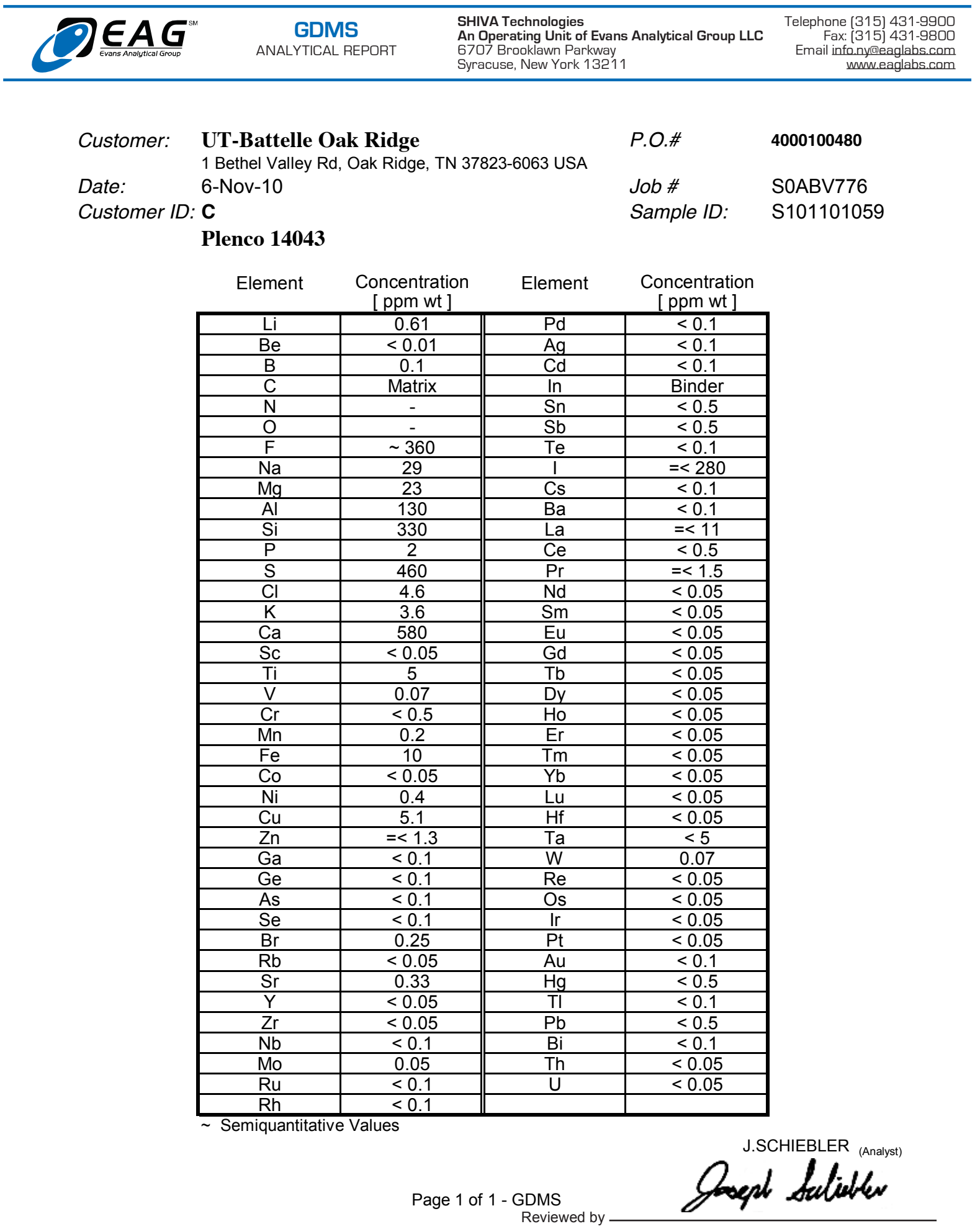

This report shall not be reproduced except in full without written approval of the laboratory. The recording of false, fictitious, or fraudulent statements or entries on the document may be punished as a felony under federal law

23 
ORNL/TM-2010/306

Table 5-5. Impurity analysis report for INL graphite/resin Blend D

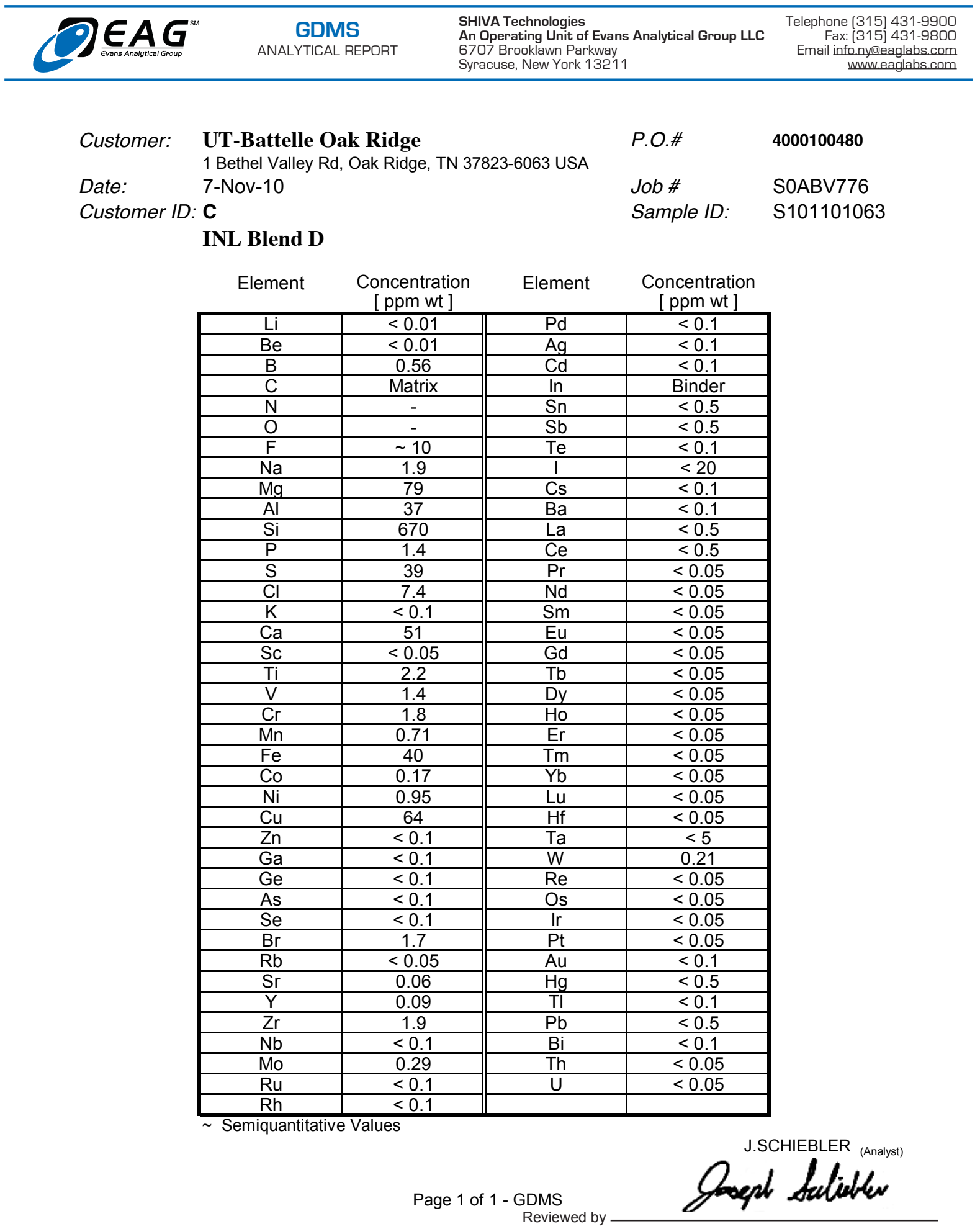

This report shall not be reproduced except in full without written approval of the laboratory. The recording of false, fictitious, or fraudulent statements or entries on the document may be punished as a felony under federal law

24 


\section{$6 \quad$ Inspection of heat-treated compact impurities}

Three heat-treated compacts were sent to Shiva Technologies for impurity analysis (see Table 1-2). Although not required by the specification, these compacts also met the requirements for diameter, length, and density placed on the compacts used for irradiation. Where possible within this limitation, compacts were selected that were machined from the same pressed cylinders as the compacts selected for irradiation.

Table 6-1 is a compilation of the impurity analysis results. The impurities in the feedstock materials were discussed in section 5. For comparison, Table 6-1 includes the impurity analysis for the matrix blend D used to make the A3-P43 compacts. Impurities that could not be detected above the analysis threshold value are reported as less than values $(<)$ and appear in gray. There is no indication that the compacting process significantly increased any of the impurity levels in the heat-treated matrix-only compacts above what was already in the matrix precursor. Some impurities were significantly reduced by the heat-treatment (e.g., $\mathrm{Na}, \mathrm{Cl}, \mathrm{Cr}, \mathrm{Fe}, \mathrm{Ni}$, and $\mathrm{Cu}$ ). $\mathrm{Mg}$ was reduced, but not as significantly. Other impurities present at moderate levels in the graphite/resin blend seemed to be somewhat reduced but were still preset at moderate levels (e.g., $\mathrm{Al}, \mathrm{S}$, and $\mathrm{Ca}$ ). The very high $\mathrm{Si}$ content from the natural graphite was reduced by about $15-30 \%$ in the heat-treated compacts, but was still very high.

Copies of the Shiva Technologies certified impurity analysis data sheets for the three heat-treated compacts are provided in Table 6-2, Table 6-3, and Table 6-4. 
Table 6-1. Summary of heat-treated compact impurities

\begin{tabular}{|c|c|c|c|c|}
\hline \multirow{2}{*}{ Element } & \multicolumn{4}{|c|}{ Concentration (ppm wt) } \\
\hline & A3-P43-Z07 & A3-P43-Z08 & A3-P43-Z15 & INL Blend D \\
\hline $\mathrm{Li}$ & $<0.01$ & $<0.01$ & $<0.01$ & $<0.01$ \\
\hline $\mathrm{Be}$ & $<0.01$ & $<0.01$ & $<0.01$ & $<0.01$ \\
\hline B & 0.11 & 0.11 & 0.12 & 0.56 \\
\hline $\mathrm{C}$ & Matrix & Matrix & Matrix & Matrix \\
\hline $\mathrm{N}$ & - & - & - & - \\
\hline $\mathrm{O}$ & - & - & - & - \\
\hline $\mathrm{F}$ & $<1$ & $<1$ & $<1$ & $\sim 10$ \\
\hline $\mathrm{Na}$ & $<0.05$ & $<0.05$ & $<0.05$ & 1.9 \\
\hline $\mathrm{Mg}$ & 19 & 28 & 10 & 79 \\
\hline $\mathrm{Al}$ & 28 & 30 & 23 & 37 \\
\hline $\mathrm{Si}$ & 560 & 570 & 480 & 670 \\
\hline $\mathrm{P}$ & 0.95 & 1.3 & 1.1 & 1.4 \\
\hline$S$ & 27 & 50 & 35 & 39 \\
\hline $\mathrm{Cl}$ & 0.43 & 0.31 & 0.16 & 7.4 \\
\hline $\mathrm{K}$ & $<0.1$ & $<0.1$ & $<0.1$ & $<0.1$ \\
\hline $\mathrm{Ca}$ & 21 & 44 & 25 & 51 \\
\hline $\mathrm{Sc}$ & $<0.05$ & $<0.05$ & $<0.05$ & $<0.05$ \\
\hline $\mathrm{Ti}$ & 0.88 & 1.9 & 1.1 & 2.2 \\
\hline $\mathrm{V}$ & 0.79 & 1.6 & 0.88 & 1.4 \\
\hline $\mathrm{Cr}$ & $<0.5$ & $<0.5$ & $<0.5$ & 1.8 \\
\hline $\mathrm{Mn}$ & $<0.05$ & $<0.05$ & $<0.05$ & 0.71 \\
\hline $\mathrm{Fe}$ & 0.17 & 0.22 & 0.08 & 40 \\
\hline $\mathrm{Co}$ & $<0.05$ & $<0.05$ & $<0.05$ & 0.17 \\
\hline $\mathrm{Ni}$ & $<0.1$ & $<0.1$ & $<0.1$ & 0.95 \\
\hline $\mathrm{Cu}$ & $<0.1$ & $<0.1$ & $<0.1$ & 64 \\
\hline $\mathrm{Zn}$ & $<0.1$ & $<0.1$ & $<0.1$ & $<0.1$ \\
\hline $\mathrm{Ga}$ & $<0.1$ & $<0.1$ & $<0.1$ & $<0.1$ \\
\hline $\mathrm{Ge}$ & $<0.1$ & $<0.1$ & $<0.1$ & $<0.1$ \\
\hline As & $<0.1$ & $<0.1$ & $<0.1$ & $<0.1$ \\
\hline $\mathrm{Se}$ & $<0.1$ & $<0.1$ & $<0.1$ & $<0.1$ \\
\hline $\mathrm{Br}$ & $<0.1$ & $<0.1$ & $<0.1$ & 1.7 \\
\hline $\mathrm{Rb}$ & $<0.05$ & $<0.05$ & $<0.05$ & $<0.05$ \\
\hline $\mathrm{Sr}$ & $<0.05$ & $<0.05$ & $<0.05$ & 0.06 \\
\hline $\mathrm{Y}$ & $<0.05$ & 0.09 & $<0.05$ & 0.09 \\
\hline $\mathrm{Zr}$ & 1.1 & 1.3 & 0.89 & 1.9 \\
\hline $\mathrm{Nb}$ & $<0.1$ & $<0.1$ & $<0.1$ & $<0.1$ \\
\hline Mo & 0.13 & 0.17 & 0.17 & 0.29 \\
\hline $\mathrm{Ru}$ & $<0.1$ & $<0.1$ & $<0.1$ & $<0.1$ \\
\hline $\mathrm{Rh}$ & $<0.1$ & $<0.1$ & $<0.1$ & $<0.1$ \\
\hline $\mathrm{Pd}$ & $<0.1$ & $<0.1$ & $<0.1$ & $<0.1$ \\
\hline $\mathrm{Ag}$ & $<0.1$ & $<0.1$ & $<0.1$ & $<0.1$ \\
\hline $\mathrm{Cd}$ & $<0.1$ & $<0.1$ & $<0.1$ & $<0.1$ \\
\hline In & $<0.1$ & $<0.1$ & $<0.1$ & Binder \\
\hline
\end{tabular}


Table 6-1. Summary of heat-treated compact impurities (continued)

\begin{tabular}{|c|c|c|c|c|}
\hline \multirow{2}{*}{ Element } & \multicolumn{4}{|c|}{ Concentration (ppm wt) } \\
\hline & A3-P43-Z07 & A3-P43-Z08 & A3-P43-Z15 & INL Blend D \\
\hline $\mathrm{Sn}$ & $<0.5$ & $<0.5$ & $<0.5$ & $<0.5$ \\
\hline $\mathrm{Sb}$ & $<0.5$ & $<0.5$ & $<0.5$ & $<0.5$ \\
\hline $\mathrm{Te}$ & $<0.1$ & $<0.1$ & $<0.1$ & $<0.1$ \\
\hline I & $<0.1$ & $<0.1$ & $<0.1$ & $<20$ \\
\hline $\mathrm{Cs}$ & $<0.1$ & $<0.1$ & $<0.1$ & $<0.1$ \\
\hline $\mathrm{Ba}$ & $<0.1$ & 0.19 & 0.17 & $<0.1$ \\
\hline $\mathrm{La}$ & $<0.5$ & $<0.5$ & $<0.5$ & $<0.5$ \\
\hline $\mathrm{Ce}$ & $<0.05$ & $<0.05$ & $<0.05$ & $<0.5$ \\
\hline $\operatorname{Pr}$ & $<0.05$ & $<0.05$ & $<0.05$ & $<0.05$ \\
\hline $\mathrm{Nd}$ & $<0.05$ & $<0.05$ & $<0.05$ & $<0.05$ \\
\hline $\mathrm{Sm}$ & $<0.05$ & $<0.05$ & $<0.05$ & $<0.05$ \\
\hline $\mathrm{Eu}$ & $<0.05$ & $<0.05$ & $<0.05$ & $<0.05$ \\
\hline $\mathrm{Gd}$ & $<0.05$ & $<0.05$ & $<0.05$ & $<0.05$ \\
\hline $\mathrm{Tb}$ & $<0.05$ & $<0.05$ & $<0.05$ & $<0.05$ \\
\hline Dy & $<0.05$ & $<0.05$ & $<0.05$ & $<0.05$ \\
\hline Ho & $<0.05$ & $<0.05$ & $<0.05$ & $<0.05$ \\
\hline $\mathrm{Er}$ & $<0.05$ & $<0.05$ & $<0.05$ & $<0.05$ \\
\hline $\mathrm{Tm}$ & $<0.05$ & $<0.05$ & $<0.05$ & $<0.05$ \\
\hline $\mathrm{Yb}$ & $<0.05$ & $<0.05$ & $<0.05$ & $<0.05$ \\
\hline $\mathrm{Lu}$ & $<0.05$ & $<0.05$ & $<0.05$ & $<0.05$ \\
\hline $\mathrm{Hf}$ & $<0.05$ & $<0.05$ & $<0.05$ & $<0.05$ \\
\hline $\mathrm{Ta}$ & $<5$ & $<5$ & $<5$ & $<5$ \\
\hline $\mathrm{W}$ & 0.13 & 0.45 & 0.35 & 0.21 \\
\hline $\mathrm{Re}$ & $<0.05$ & $<0.05$ & $<0.05$ & $<0.05$ \\
\hline Os & $<0.05$ & $<0.05$ & $<0.05$ & $<0.05$ \\
\hline $\mathrm{Ir}$ & $<0.05$ & $<0.05$ & $<0.05$ & $<0.05$ \\
\hline $\mathrm{Pt}$ & $<0.05$ & $<0.05$ & $<0.05$ & $<0.05$ \\
\hline $\mathrm{Au}$ & $<0.1$ & $<0.1$ & $<0.1$ & $<0.1$ \\
\hline $\mathrm{Hg}$ & $<0.5$ & $<0.5$ & $<0.5$ & $<0.5$ \\
\hline $\mathrm{Tl}$ & $<0.1$ & $<0.1$ & $<0.1$ & $<0.1$ \\
\hline $\mathrm{Pb}$ & $<0.5$ & $<0.5$ & $<0.5$ & $<0.5$ \\
\hline $\mathrm{Bi}$ & $<0.1$ & $<0.1$ & $<0.1$ & $<0.1$ \\
\hline $\mathrm{Th}$ & $<0.05$ & $<0.05$ & $<0.05$ & $<0.05$ \\
\hline $\mathrm{U}$ & $<0.05$ & $<0.05$ & $<0.05$ & $<0.05$ \\
\hline
\end{tabular}


ORNL/TM-2010/306

Table 6-2. Impurity analysis report for heat-treated compact A3-P43-Z07

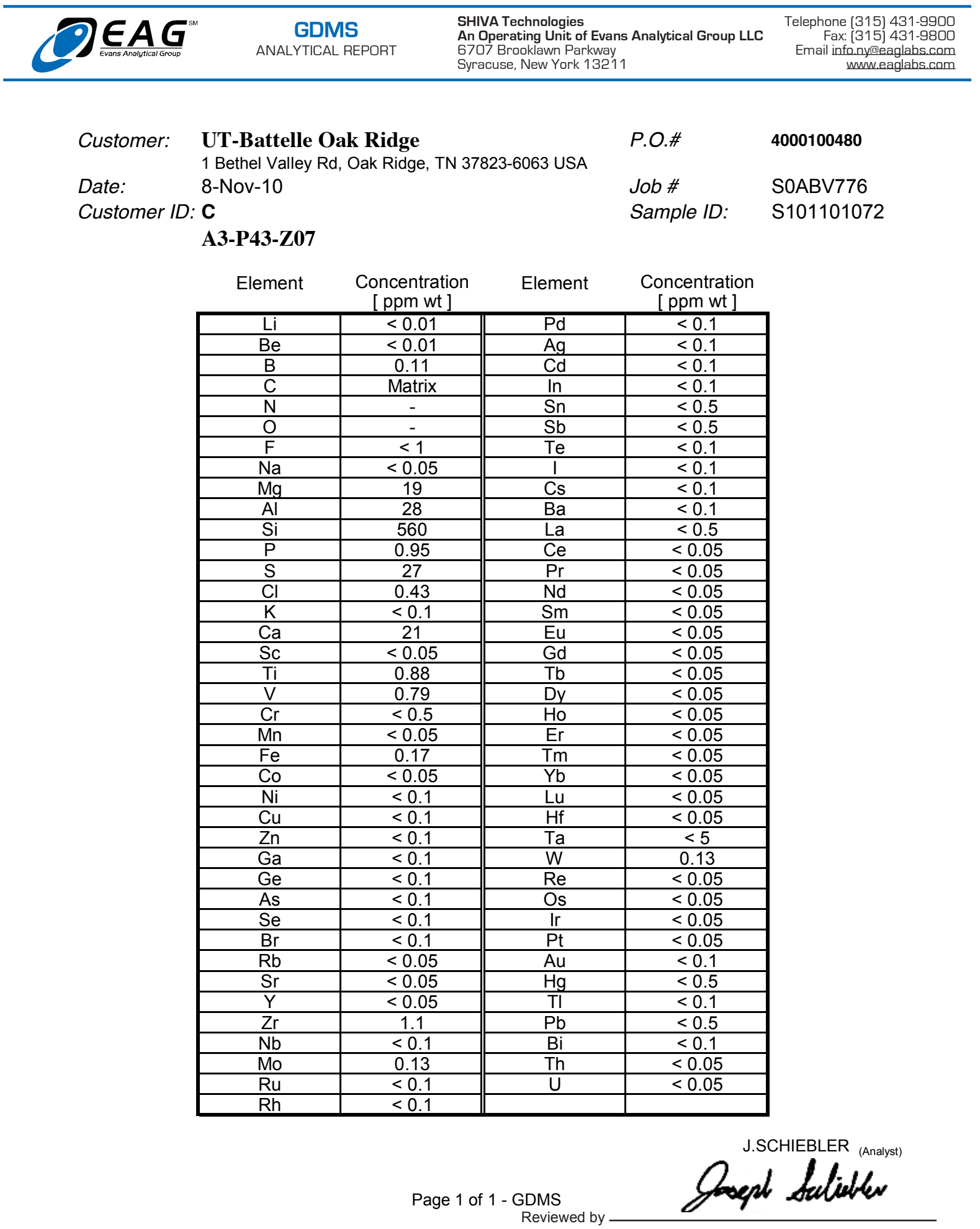

This report shall not be reproduced except in full without written approval of the laboratory. The recording of false, fictitious, or fraudulent statements or entries on the document may be punished as a felony under federal law

28 
ORNL/TM-2010/306

Table 6-3. Impurity analysis report for heat-treated compact A3-P43-Z08

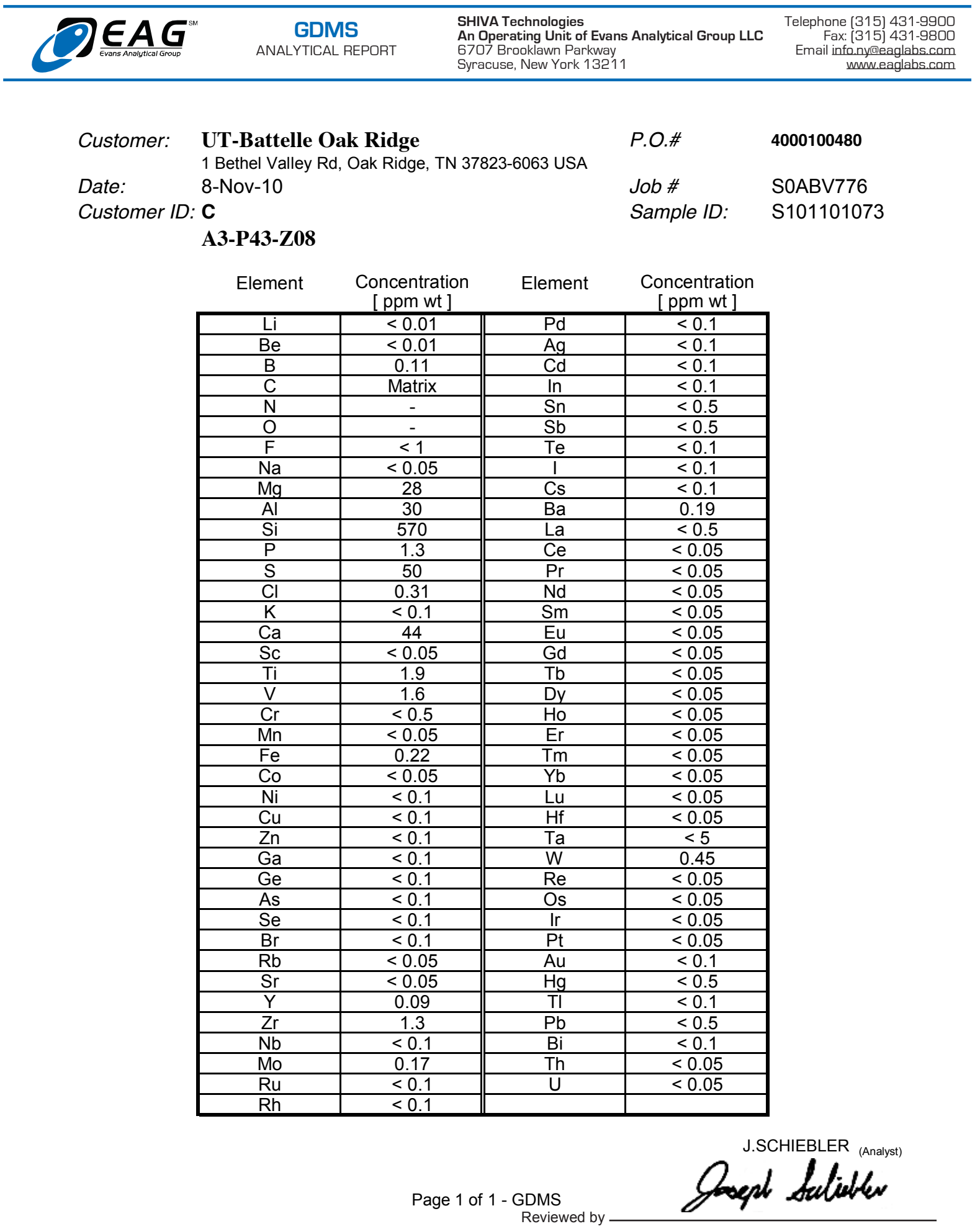

This report shall not be reproduced except in full without written approval of the laboratory. The recording of false, fictitious, or fraudulent statements or entries on the document may be punished as a felony under federal law

29 
ORNL/TM-2010/306

Table 6-4. Impurity analysis report for heat-treated compact A3-P43-Z15

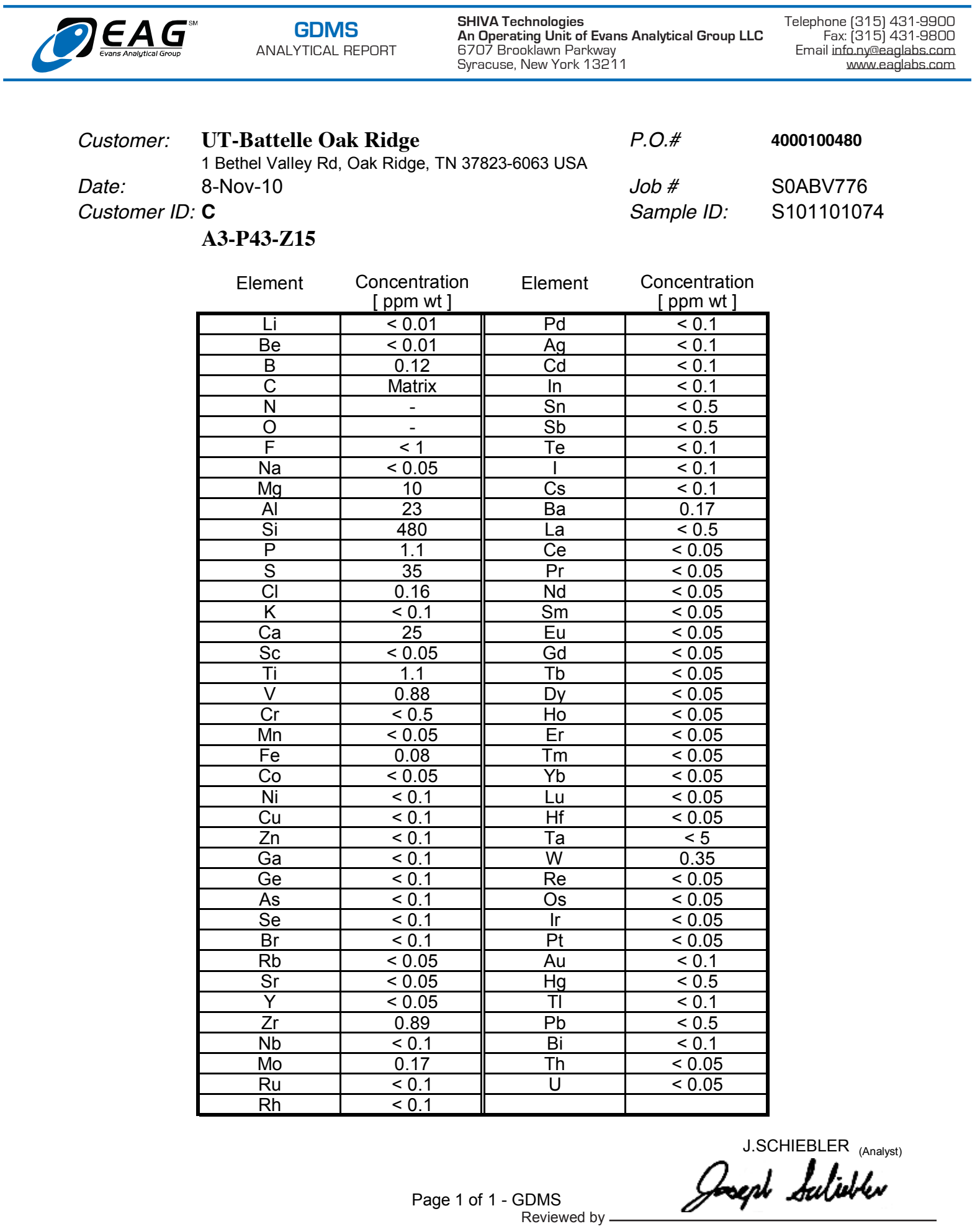

This report shall not be reproduced except in full without written approval of the laboratory. The recording of false, fictitious, or fraudulent statements or entries on the document may be punished as a felony under federal law

30 


\section{Appendix A: Compact Machining Drawings}

Prior to heat-treatment, carbonized cylinders were machined according to drawing AGR-COMPDWG-03, "AGC Compact Drawing". Copies of these drawings are attached in this appendix. 


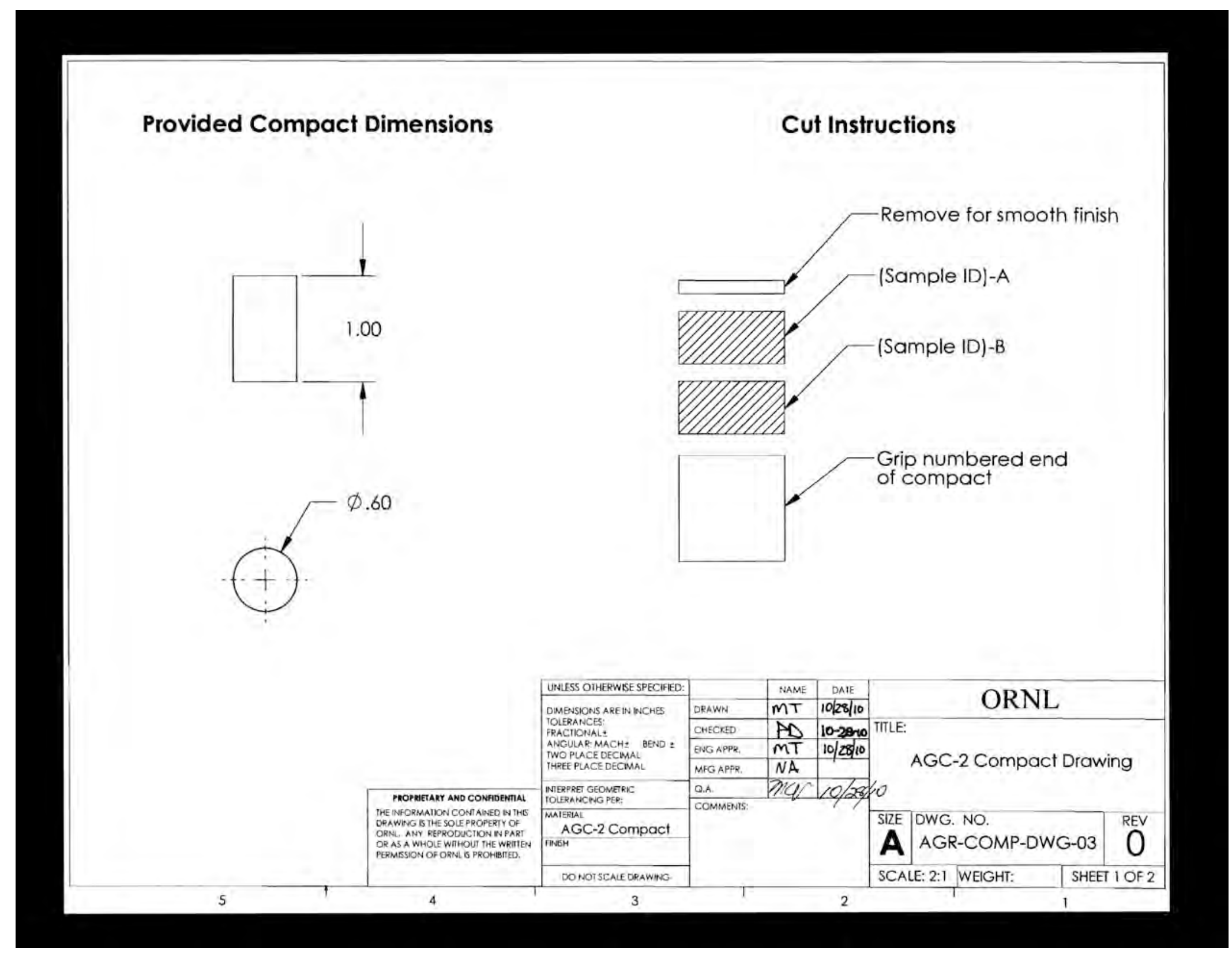




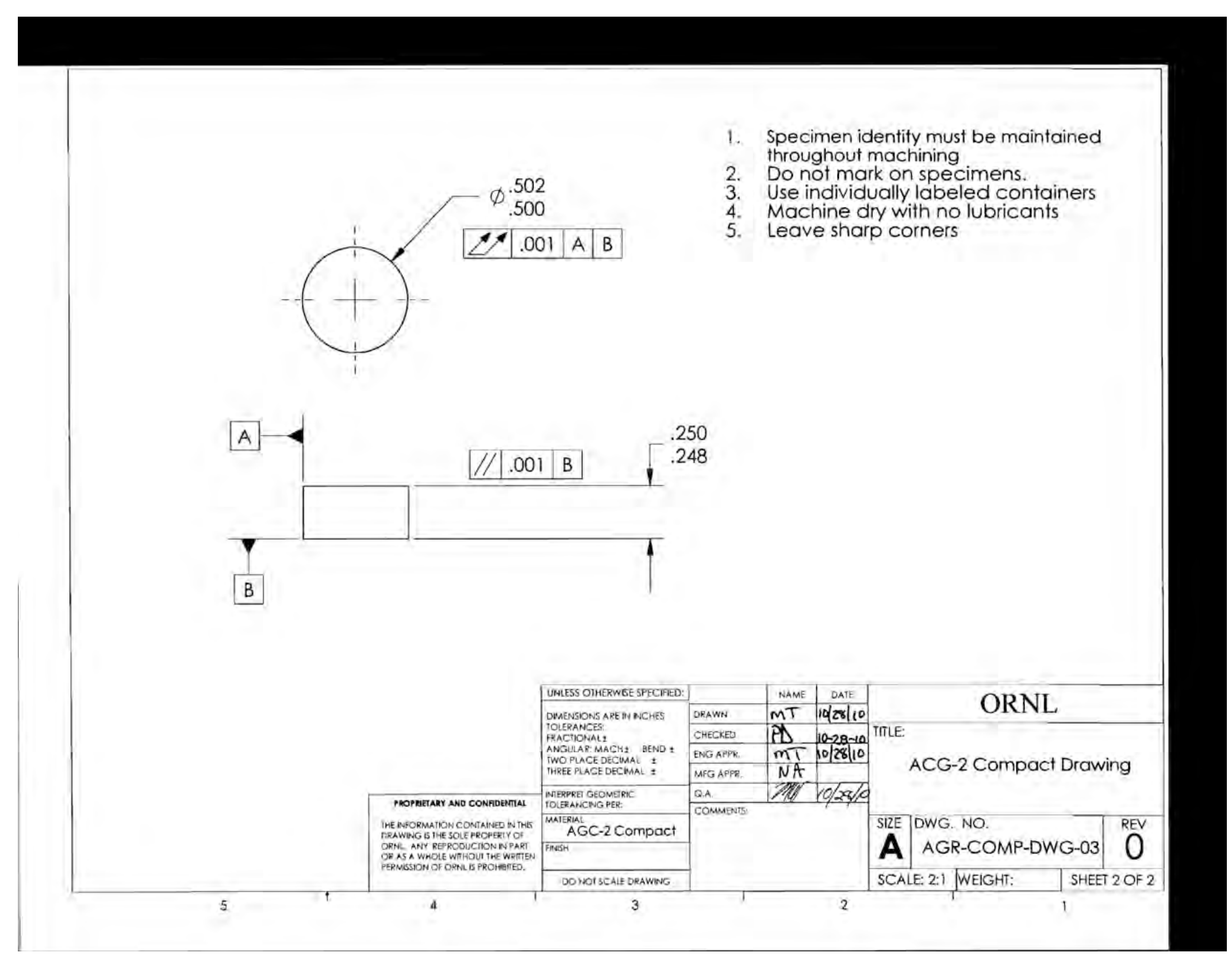




\section{Appendix B: Certificate of Conformance}

This section contains the Certificate of Conformance for the A3-P43 compact lot. This is a record of the review by Quality Assurance personnel that specified requirements in INL SPC1285, Rev. 1 have been met. All compacts selected for irradiation or impurity analysis met all dimensional and density specifications. Note that the specification only requires compacts used for irradiation meet these requirements, so the final determination of this inspection is that the product (compacts used for irradiation) conforms to the specified requirements for length, diameter, and density. 
Oak Ridge National Laboratory

\section{Advanced Gas Reactor Fuel Development and Qualification Program CERTIFICATE OF CONFORMANCE}

\begin{tabular}{|c|c|c|c|c|c|c|c|c|c|}
\hline \multicolumn{10}{|c|}{$\begin{array}{l}\text { 1. ITEM IDENTIFICATION: AGC-2 Matrix-only Compacts } \\
\text { 2. PART LOT AND LOT NUMBER: INL Blend D with Plenco 14043, Lot A3-P43 } \\
\text { 3. PRODUCT DEFINITION: INL SPC-1285, Revision 1, Matrix Compacts for AGC-2 Irradiation } \\
\text { 4. LIST OF APPROVED DEVIATIONS: Not Applicable }\end{array}$} \\
\hline $\begin{array}{l}\text { *Part } \\
\text { Type }\end{array}$ & $\begin{array}{l}\text { Unique Part } \\
\text { I.D. No. }\end{array}$ & QTY & INIT. & Date & $\begin{array}{l}* \text { Part } \\
\text { Type }\end{array}$ & $\begin{array}{l}\text { Unique Part } \\
\text { I.D. No. }\end{array}$ & QTY & INIT. & Date \\
\hline $\mathrm{MC}$ & A3-P43-Z03 & 1 & $\mathbb{P}$ & Uliso & & & & & \\
\hline $\mathrm{MC}$ & A3-P43-Z12 & 1 & III & 1) & & & & & \\
\hline $\mathrm{MC}$ & A3-P43-Z06 & 1 & MIa & Ulilio & & & & & \\
\hline & & & & & & & & & \\
\hline & & & & & & & & & \\
\hline & & & & & & & & & \\
\hline & & & & & & & & & \\
\hline & & & & & & & & & \\
\hline & & & & & & & & & \\
\hline & & & & & & & & & \\
\hline & & & & & & & & & \\
\hline & & & & & & & & & \\
\hline & & & & & & & & & \\
\hline & & & & & & & & & \\
\hline & & & & & & & & & \\
\hline & & & & & & & & & \\
\hline & & & & & & & & & \\
\hline & & & & & & & & & \\
\hline & & & & & & & & & \\
\hline & & & & & & & & & \\
\hline & & & & & & & & & \\
\hline & & & & & & & & & \\
\hline & & & & & & & & & \\
\hline & & & & & & & & & \\
\hline
\end{tabular}

\section{LIST OF APPLICABLE NONCONFORMANCE REPORT NUMBERS: Not Applicable}

With the exception of the Deviations documented on the forms referenced in Item 4 and the nonconforming conditions documented on Nonconformance Reports referenced in Item 5, the listed parts have been produced and tested in compliance to the requirements of the QAP for the AGR Program at ORNL

(Document \# QAP-ORNL-AGR-01), its subordinate implementing procedures, and to the specified product definition prescribed in the document(s) referenced in Item 3.

M. C. Vance, AGR Quality Representative,

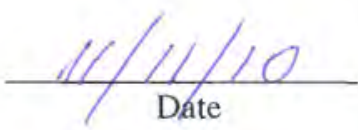

Fuel Cycle and Isotopes Division, ORNL

* MC indicates matrix-only compact 